Article

\title{
The Influence of a Polymer Powder on the Properties of a Cold-Recycled Mixture with Foamed Bitumen
}

\author{
Przemysław Buczyński *(D) and Marek Iwański (iD) \\ Department of Transportation Engineering, Faculty of Civil Engineering and Architecture, Kielce University of \\ Technology, Al. Tysiąclecia Państwa Polskiego 7, 25-314 Kielce, Poland; iwanski@tu.kielce.pl \\ * Correspondence: p.buczynski@tu.kielce.pl; Tel.: +48-41-34-24-560
}

Received: 7 November 2019; Accepted: 13 December 2019; Published: 17 December 2019

\begin{abstract}
The paper investigates the influence of redispersible polymer powder (RPP) on the physical and mechanical properties of a cold-recycled mixture with foamed bitumen (CRM-FB). Four types of RPP with a varied chemical base were used: VA-VeoVA, VA-VeoVa-Ac, EVA and VA/VV/E/Ac. The polymer powder-modified cold recycled mixture with foamed bitumen, (P)CRM-FB, was composed of $45.8 \%$ reclaimed asphalt pavement (RAP), $45.8 \%$ natural aggregate (VA), 3.0\% Portland cement CEM I 42,5R, 3.0\% foamed bitumen 50/70 and 3.0\% RPP, all dosed by weight. The reference mixture, (R)CRM-FB, served as a reference point for comparison. It was found that RPP improved the workability of the CRM-FB mixture. This results in a reduced number of compaction cycles and lower energy needed to obtain the air void content as in the reference mixture. In addition, the RPP modifier markedly increased the CRM-FB mixture cohesion $\left(I_{T S} S_{D R Y}\right)$ and strength, by approximately $40-70 \%$, depending on the RPP used. These findings are particularly important for CRM-FB mixtures designed for road bases. The present investigations confirmed the improvement of the CRM-FB mixture parameters after the modification with RPP, regardless of the powder type used.
\end{abstract}

Keywords: polymer; redispersible polymer powder; foamed bitumen; recycling; cold mixtures; cold recycled mixture

\section{Introduction}

Cold deep in place recycling is an established road rehabilitation solution used in Poland [1,2] and worldwide [3,4]. The durability and fatigue life of cold, half-warm [5] and hot mixture asphalt pavements depend on multiple factors. The skid resistance [6] is responsible for the safety of users, and the fatigue life of pavement layers depends on the type of binders [7-9], additives [10] and mineral components used, that is, aggregate [11] and reclaimed asphalt pavement (RAP) [12]. Common additives in cold deep recycled mixtures with foamed bitumen and bitumen emulsion include: cement, lime, ash (waste from cement production) [13] and hydraulic binders, which generally increase cohesion, hence, durability, and in some cases improve the resistance to weather (moisture, interaction of moisture and frost). The composition of a cold-recycled mixture may cause many problems. As demonstrated by the authors of [14], incorrectly designed cold-recycled mixtures may become excessively stiff, which leads to the formation of shrinkage cracks in the base course. In turn, an insufficient amount of cement may reduce indirect tensile strength and thus shorten the fatigue life [15]. Therefore, finding a solution to improve fatigue life without increasing the stiffness modulus of the cold-recycled mixture with foamed bitumen and cement seems critical.

Polymers impart resilience to construction materials and improve their ductility by significantly altering their properties. Mazurek and Iwański reported the benefits of using highly modified bitumen in stone mastic asphalt (SMA) mixtures [16]. Improved properties of polymer-modified bitumen have been confirmed in a number of other studies [17-19]. Polymers find many applications in cement 
concrete and cement-based materials. Various forms and types of polymers are used both to modify cement concrete mixtures and to produce polymer-cement concretes (PCC), polymer-impregnated concretes (PIC) and polymer concretes (PC) [20]. In [21], Kim et al. presented an application of EVA polymer to the production of polymer-modified cement mortar (PCM), a widely used repair material for reinforced concrete $(\mathrm{RC})$ structures due to its excellent strength and durability. Successful testing of the addition of polymers to cement concrete was described by Gutarowska et al. [22] and Shen et al. [23].

Considering the results of the studies above, supporting the benefits from adding polymers to cement concrete, paving-grade bitumen and asphalt mixtures, it seems necessary to determine the effects of polymers on the properties of cold-recycled mixtures with foamed bitumen (CRM-FB).

The main aims of the article are to explain how the CRM properties are modified by the addition of redispersible polymer powders (RPPs) and to confirm that the transfer of polymer properties to the CRM properties in terms of increased cohesion, increased elasticity of the mixture and increased ductility will reduce the risk of shrinkage cracks in road bases containing hydraulic binder. The results of these analyses will contribute to broadening both the scope of knowledge on the cold deep recycling with foamed bitumen and the scope of their application to road rehabilitation and reconstruction.

\section{Aim and Scope of Study}

The present article aimed to investigate the changes in physical and mechanical properties of a cold recycled mixture with foamed bitumen (CRM-FB) after the modification of its structure with a redistributable polymer powder (RPP). The investigations of mechanical properties were focused on the assessment of indirect tensile strength (ITS) and properties related to the stiffness of the recycled mixture. Considering the mechanism of polymer interaction with the properties of building materials, the application of RPPs in the composition of a CRM-FB mixture should increase the cohesion of the CRM-FB without increasing its stiffness. Confirmation of this relationship will show that the modification of the CRM-FB structure has been achieved. Statistical tools in the form of multiple comparison tests with the Tukey test were used. The grouping evaluation showed similar effects of polymer powders with different chemical bases on a given characteristic. The results revealed similarities and differences between the modifiers in terms of the effect on the properties of CRM-FB mixtures. Figure 1 shows a block diagram of the experimental design. 


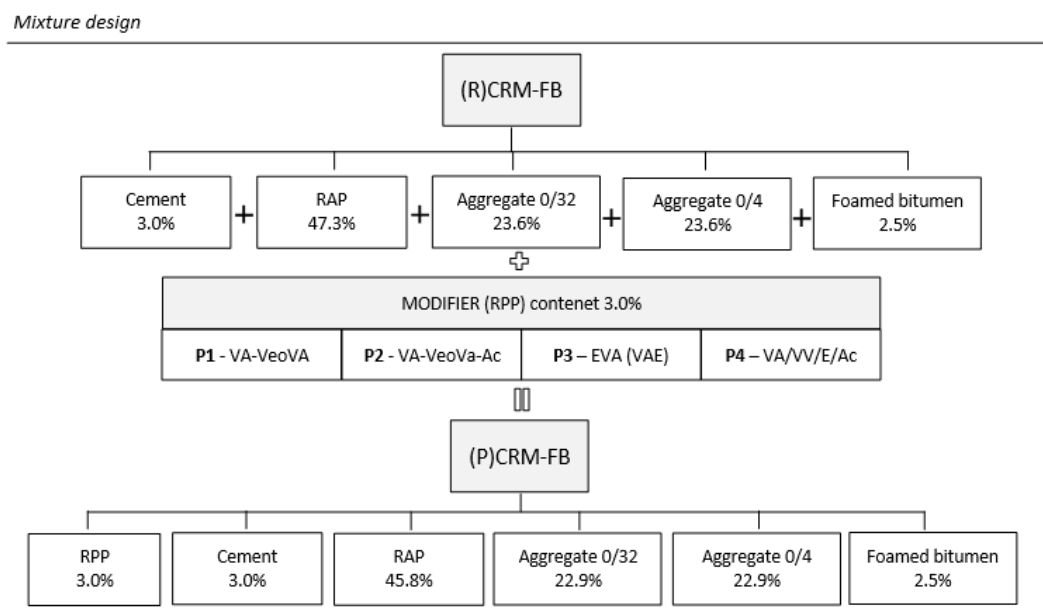

Experimental program

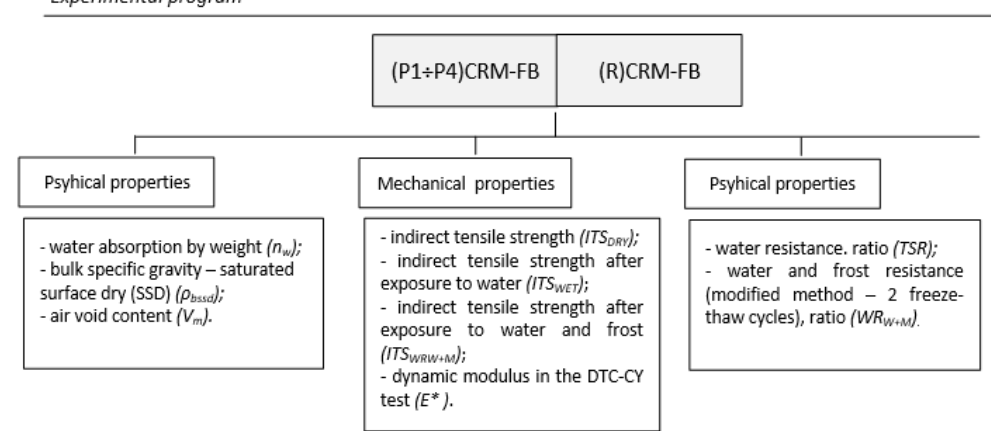

Figure 1. Experimental design.

\section{Materials}

\subsection{Redispersible Polymer Powder}

Four types of redispersible polymer powder with different base polymers were used in the tests. They included thermoplastic copolymers (plastomers), where the protective colloid was polyvinyl alcohol (PVA) for preventing the particles from coalescing during the spray drying of the dispersion [20]. Table 1 compiles the most important information about RPPs, adapted from [24].

Table 1. Redispersible polymer powders used [25].

\begin{tabular}{ccccc}
\hline Code & Description & Name & $\begin{array}{c}\text { Bulk Density } \\
\text { ISO 679 (g/L) }\end{array}$ & Base Polymer \\
\hline P1 & VA-VeoVA & $\begin{array}{c}\text { vinyl acetate-vinyl versatate copolymer } \\
\text { vinyl acetate-vinyl versatate-acrylate } \\
\text { copolymer }\end{array}$ & $550-570$ & $\begin{array}{c}\text { vinyl acetate and vinyl } \\
\text { versatate }\end{array}$ \\
P2 & VA-VeoVa-Ac & $\begin{array}{c}530-670 \\
\text { ethylene-vinyl acetate copolymer } \\
\text { vinyl acetate-vinyl }\end{array}$ & $\begin{array}{c}\text { butyl acrylate, vinyl acetate } \\
\text { and vinyl versatate } \\
\text { ethylene and vinyl acetate }\end{array}$ \\
P4 & EVA (VAE) & VA/VV/E/Ac & $\begin{array}{c}\text { versatate-ethylene-acrylate copolymer } \\
\text { ethylene, vinyl acetate, vinyl } \\
\text { versatate and butyl acrylate }\end{array}$ \\
\hline
\end{tabular}

The polymers used in the experiment had the form of a redispersible powder obtained through the evaporation of water from polymer emulsions. Redispersible polymer powders are polymer emulsions transformed into a powder through a series of processes such as heat treatment, pressure and spray drying [26]. When mixed with water, the powder re-disperses in water back into polymer emulsion. Examples of redispersible powders under analysis are shown in Figure 2 (powder), Figure 3 (after mixing with water at $24 \mathrm{~h}$ of sedimentation) and Figure 4 (continuous polymer phase). 


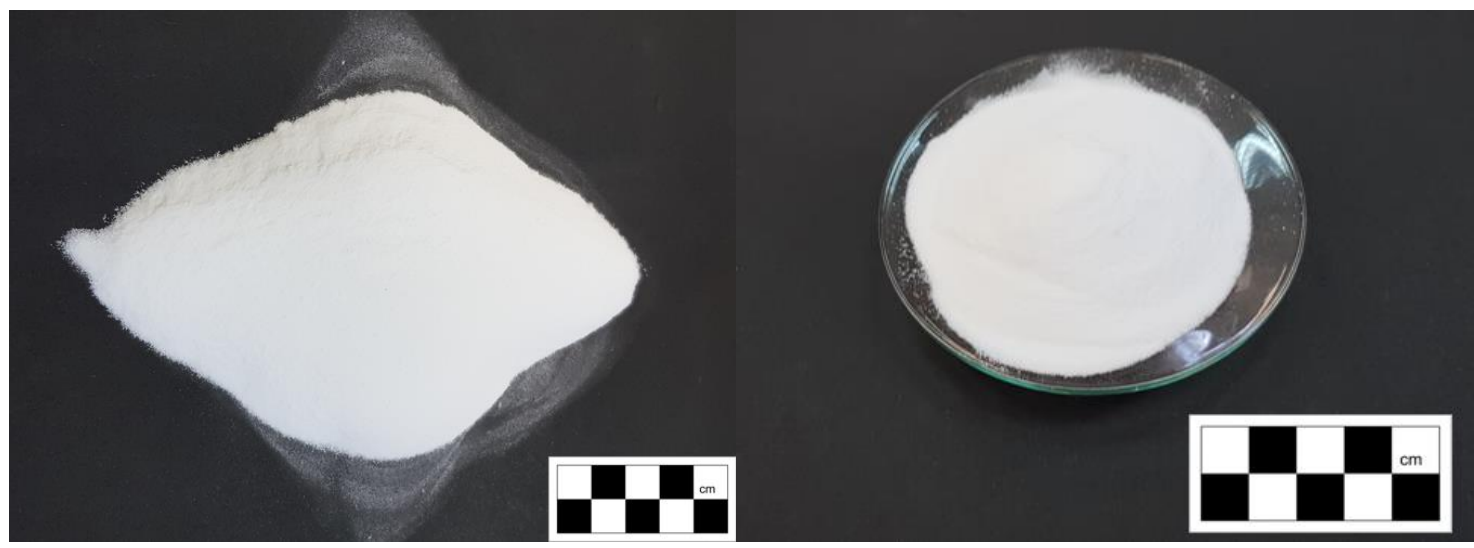

a)

b)

Figure 2. Redispersible polymer powders: (a) ethylene-vinyl acetate copolymer (EVA) and (b) vinyl acetate-vinyl versatate copolymer (VA-VeoVA).

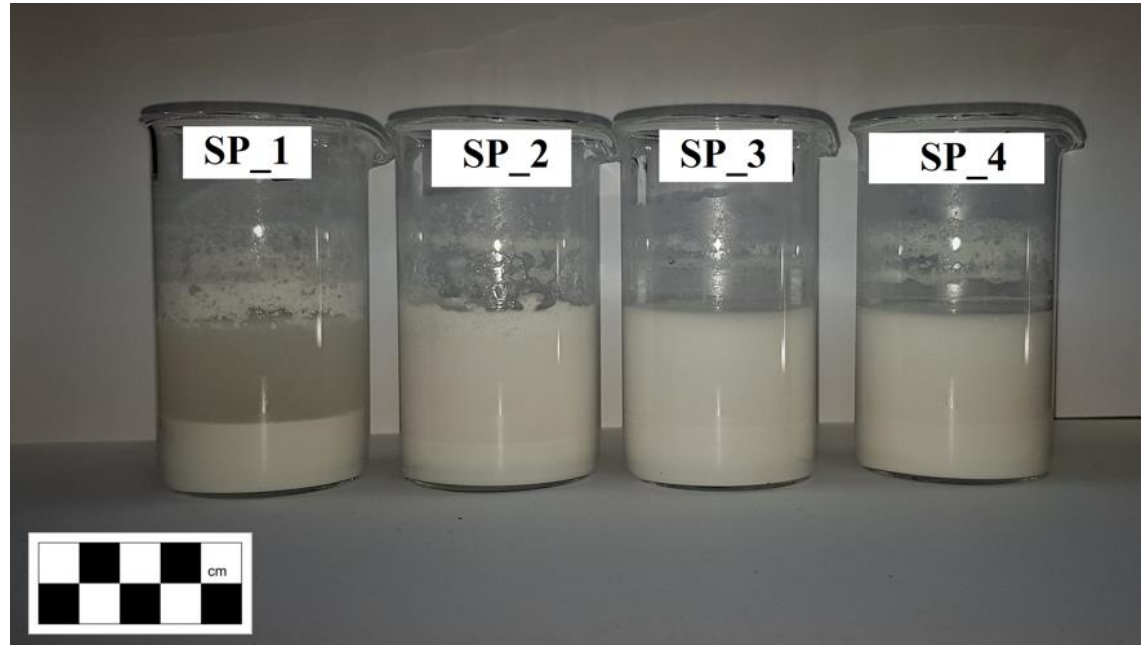

Figure 3. Redispersible polymer powders-polymer emulsion.

Figure 3 shows the de-emulsification and (in the case of SP2) flocculation of the RPPs $24 \mathrm{~h}$ after mixing with water. It should also be noted that in each case, the liquid phase and the solid phase were separated as a result of sedimentation (Figure 3). Similar phenomena were observed by the authors of [27]. The heaviest particles, in the form of the base polymer, sink to the bottom, whereas the protective colloid, in the form of polyvinyl alcohol (PVA), is dissolved in water [28], coloring it white.

A uniform continuous phase of the base polymer was achieved after the sedimented material was dried (Figure 4). A trace amount of the protective colloid was found on the surface in the form of a white powder. 


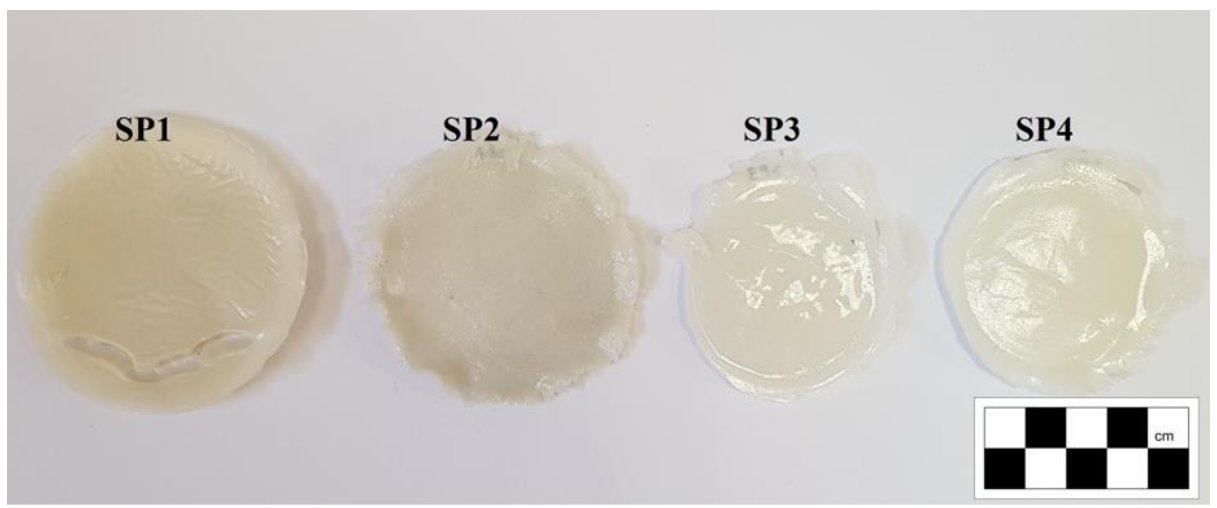

Figure 4. Continuous polymer phase.

The protective colloid content was also determined during the tests as the parts soluble in water. This was done by determining the weight loss after the polymer dissolved in the water and dried to constant weight in a dryer with a fan at $105 \pm 5^{\circ} \mathrm{C}$. The results of the analysis are given in Table 2 .

Table 2. Percentage of soluble part in redistributable polymer powder (RPP).

\begin{tabular}{ccccc}
\hline Code & Description & $\mathbf{X}$ & $\mathbf{s}$ & $\boldsymbol{v}(\mathbf{\%})$ \\
\hline P1 & VA-VeoVA & 4.6 & 0.37 & 8.0 \\
P2 & VA-VeoVa-Ac & 4.6 & 0.42 & 9.3 \\
P3 & EVA (VAE) & 5.0 & 0.30 & 5.9 \\
P4 & VA/VV/E/Ac & 4.8 & 0.34 & 7.1 \\
\hline
\end{tabular}

The contents of the protective colloid/parts soluble in water (Table 2) were very similar, regardless of the RPP type analyzed.

Scanning electron microscopy/energy dispersive X-ray spectrometry (SEM/EDS) was used for in-depth assessment of the microstructure and chemical composition of the RPPs. The material was examined under low-vacuum conditions (pressure of $30 \mathrm{~Pa}$ ). Sample images of the RPP microstructure are shown in Figure 5. The point that was analyzed for chemical composition was marked red. Table 3 summarizes the results of chemical analysis.

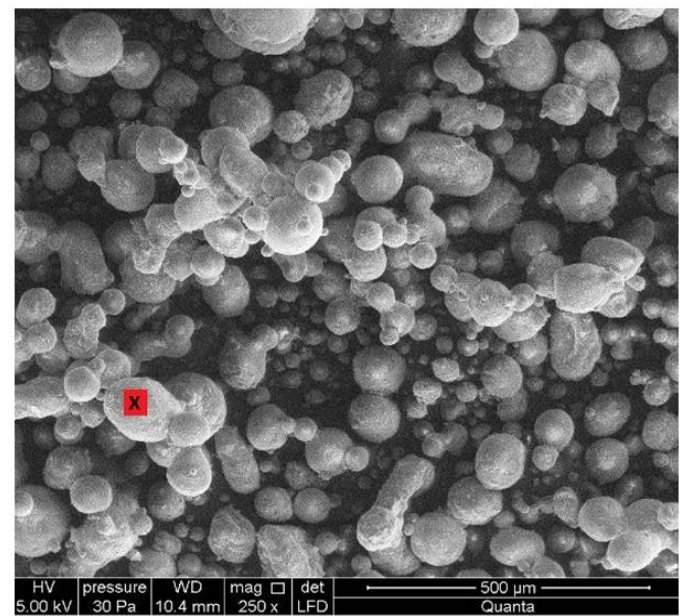

a)

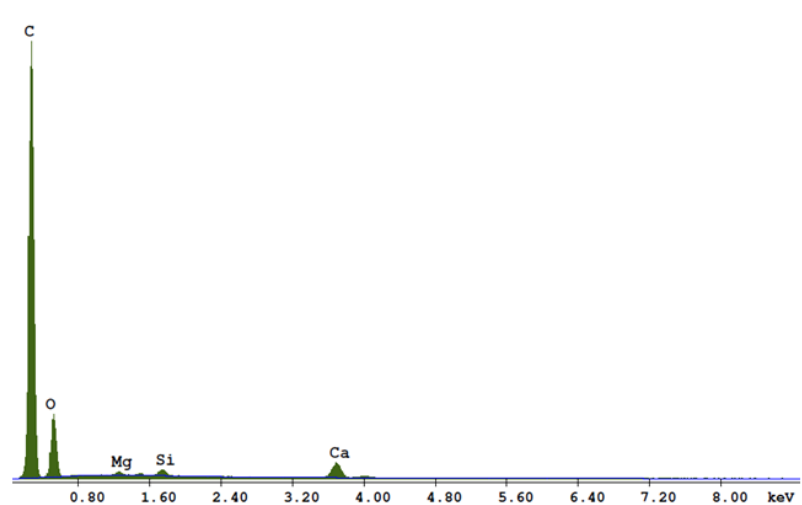

$\left.a^{\prime}\right)$

Figure 5. Cont. 


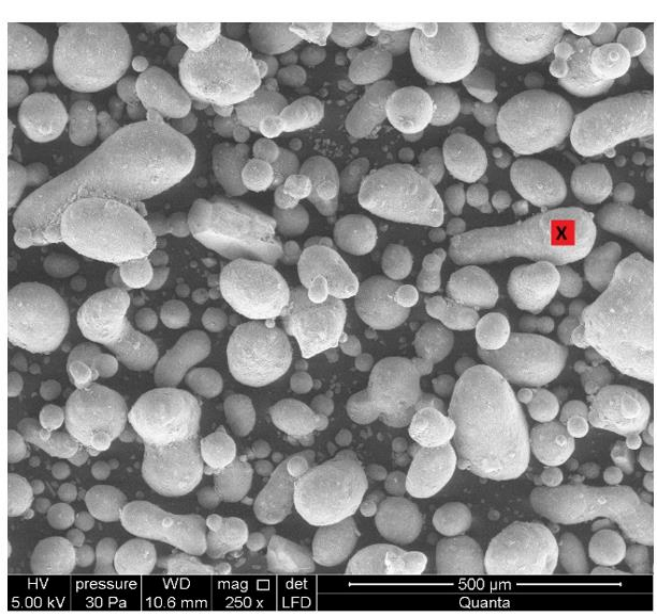

b)

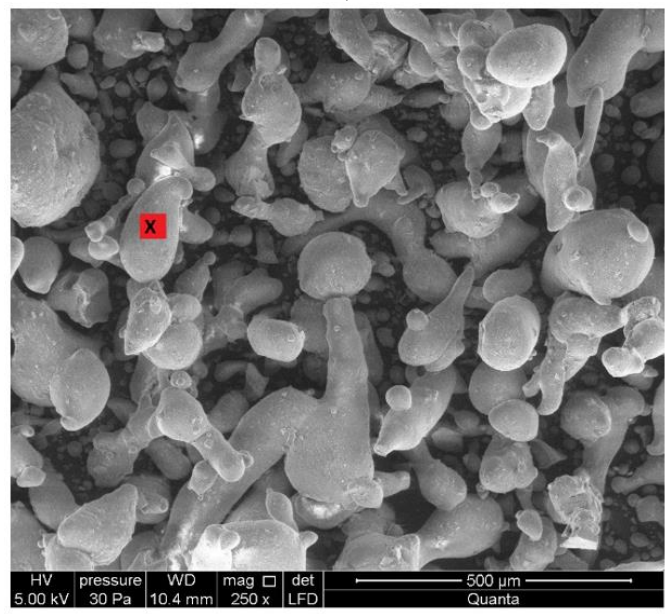

c)

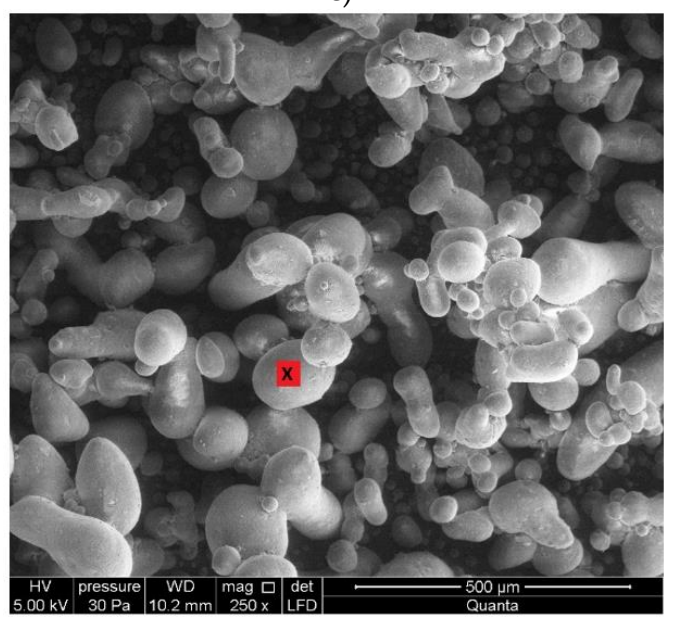

d)

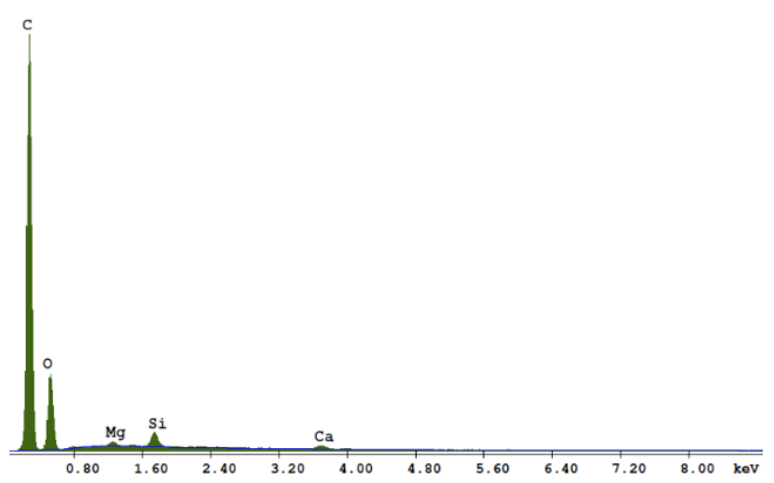

$\left.b^{\prime}\right)$

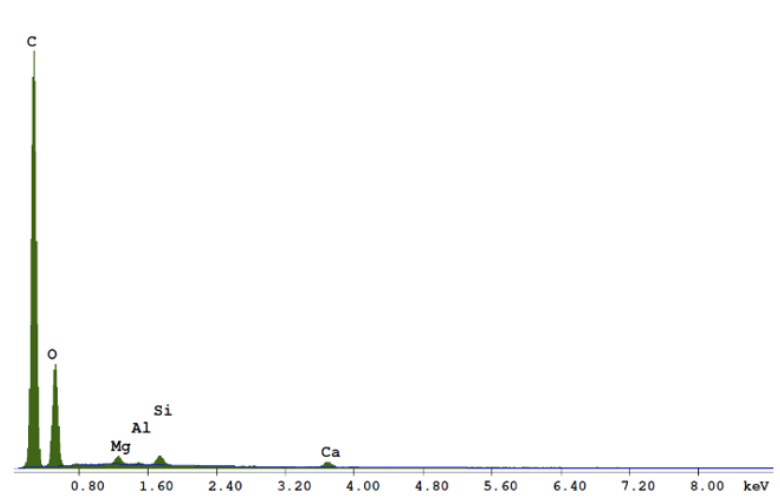

$\left.c^{\prime}\right)$

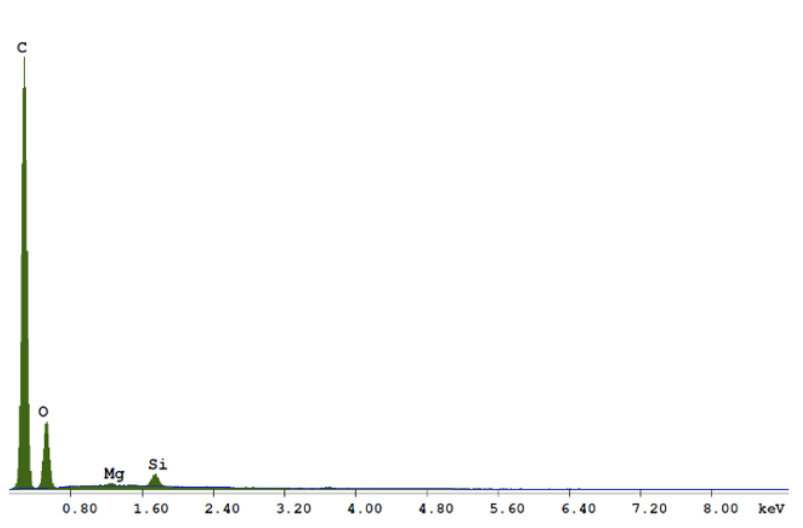

$\left.d^{\prime}\right)$

Figure 5. Microstructure of RPPs: (a) SEM for P1 (VA-VeoVA); (a') EDX graph for P1 (VA-VeoVA) (b) SEM for P2 (VA-VeoVA-A); (b') EDX graph for P2 (VA-VeoVA-A); (c) SEM for EVA (VAE); (c') EDX graph for EVA (VAE); (d) SEM for VA/VV/E/Ac; (d') EDX graph for VA/VV/E/Ac. 
Table 3. Chemical composition of the RPPs.

\begin{tabular}{ccccc}
\hline Component & $\begin{array}{c}\text { Percentage in P1 } \\
\mathbf{( \% )}\end{array}$ & $\begin{array}{c}\text { Percentage in P2 } \\
\mathbf{( \% )}\end{array}$ & $\begin{array}{c}\text { Percentage in P3 } \\
\mathbf{( \% )}\end{array}$ & $\begin{array}{c}\text { Percentage in P4 } \\
\mathbf{( \% )}\end{array}$ \\
\hline $\mathrm{C}$ & 67.35 & 67.85 & 67.67 & 71.25 \\
$\mathrm{O}$ & 24.80 & 27.44 & 29.13 & 26.03 \\
$\mathrm{Mg}$ & 0.53 & 0.70 & 0.52 & 0.40 \\
$\mathrm{Si}$ & 1.04 & 2.54 & 1.65 & 2.31 \\
$\mathrm{Ca}$ & 6.28 & 1.47 & 0.75 & 0.0 \\
$\mathrm{Al}$ & 0.0 & 0.0 & 0.29 & 0.0 \\
$\mathrm{~S}$ & 100.00 & 100.00 & 100.00 & 100.00 \\
\hline
\end{tabular}

The morphology of the RPPs showed no relationship between the type of the base polymer and the shape of the powder particles. The shape and size of the powder particles depend on the production process $[29,30]$. According to the literature [20], the polymer particle size in redispersible powders is usually within the range of $1-10 \mu \mathrm{m}$. The shape of the particles was most similar to a sphere with a tendency for elongation. Analysis of the composition showed the predominance of carbon with traces of magnesium, aluminum and silicon.

\subsection{Aggregate}

Two types of mineral component, i.e., natural aggregate and reclaimed aggregate, were used in the CRM-FB mixture. The aggregate was natural crushed fine dolomite $0 / 4 \mathrm{~mm}(\mathrm{VA}(0 / 4))$ and $0 / 31.5 \mathrm{~mm}$ (VA (0/31.5)). The bulk density of the grains was as follows: $0 / 4 \mathrm{~mm}: \rho_{\mathrm{a}}=2.68 \mathrm{Mg} / \mathrm{m}^{3}, 0 / 31.5 \mathrm{~mm}$ : $\rho_{\mathrm{a}}=2.80 \mathrm{Mg} / \mathrm{m}^{3}$ and reclaimed asphalt pavement (RAP) $\rho_{\mathrm{a}}=2.43 \mathrm{Mg} / \mathrm{m}^{3}$. The type of aggregate was selected in terms of grain size for the required continuous grading of the asphalt mixture. The grading curves of the mineral components are shown in Figure 6.

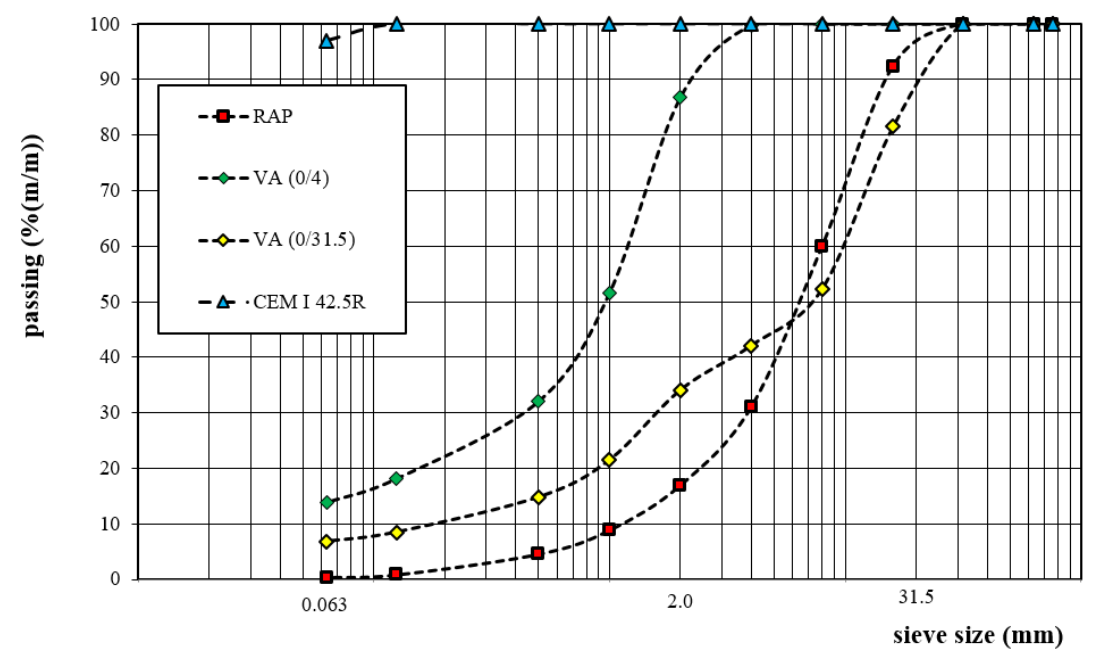

Figure 6. Grading curves of mineral materials.

Detailed identification of the RAP components was performed focusing on the bitumen type. The tests were carried out in accordance with a series of standards: EN 12697-1 for the amount of soluble asphalt and EN 933-1 + EN 12697-2 for the particle size distribution of the mineral mixture. The analysis of the test results showed $4.8 \%$ binder content, $10.9 \%$ filler fraction $(\leq 0.063 \mathrm{~mm}), 35.8 \%$ sand $(0.063 \div$ $2.0 \mathrm{~mm}$ ) and $53.3 \%$ mastic ( $\geq 2 \mathrm{~mm}$ ). To evaluate the type of bitumen, an appropriate amount of the binder was extracted from the mixture and recovered in a rotary evaporator in accordance with the procedure set forth in EN 12697-3 [31]. Test results of the bitumen samples are compiled in Table 4. 
Table 4. Test results of the bitumen extracted from reclaimed asphalt pavement (RAP).

\begin{tabular}{cccccc}
\hline Bitumen Parameter & Testing Method & Unit & Result & Stand. Dev. & Coeff. of Variation \\
\hline Binder content & PN-EN 12697-1 & $\%$ & 4.8 & 0.1 & 1.9 \\
Penetration at $25^{\circ} \mathrm{C}$ & PN-EN 1426 & $0.1 \mathrm{~mm}$ & 35.0 & 1.3 & 3.7 \\
Softening temperature & PN-EN 1427 & ${ }^{\circ} \mathrm{C}$ & 59.8 & 1.7 & 2.9 \\
Elastic recovery & PN-EN 13398 & $\%$ & 12.0 & 1.2 & 9.6 \\
\hline
\end{tabular}

The results indicate that the RAP contained 35/50 paving-grade bitumen.

\subsection{Foamed Bitumen}

Foamed bitumen was produced with a sol-gel bitumen 50/70. Before foaming, basic parameters of the RAP-extracted bitumen were determined to the relevant standard [32]. Table 5 shows the results.

Table 5. Standard test results for the bitumen 50/70.

\begin{tabular}{cccc}
\hline Parameter & Unit & Standard & Result \\
\hline & & & $50 / 70$ \\
Penetration & $0.1 \mathrm{~mm}$ & PN-EN 1426 & 60.0 \\
Softening point & ${ }^{\circ} \mathrm{C}$ & PN-EN 1427 & 50.2 \\
Fraass breaking point & ${ }^{\circ} \mathrm{C}$ & PN-EN 12593 & -15.0 \\
\hline
\end{tabular}

The use of paving-grade bitumen for foaming, and hence, as a component in CRM-FB mixtures requires that the bitumen foaming characteristics and optimum foaming water content (OFWC) be determined. The amount of water required for bitumen foaming was determined in accordance with the procedure described in relevant guidelines [33]. Additionally, the suitability of the bitumen for foaming is evaluated with respect to two parameters, the maximum expansion ratio (ERm) and half-life H-L [33]. The minimum value of these parameters depends on the temperature of the aggregate surrounded by foamed bitumen $[33,34]$, and it should be equal to:

- $\quad \mathrm{ERm} \geq 10$ and $\mathrm{HL} \geq 8 \mathrm{~s}$ for aggregate temperatures from 10 to $15^{\circ} \mathrm{C}$,

- $\quad \mathrm{ERm} \geq 8$ and $\mathrm{HL} \geq 6 \mathrm{~s}$ for aggregate temperatures above $15^{\circ} \mathrm{C}$.

Since the mixture was prepared under laboratory conditions, the minimum values were as those for aggregate at $\geq 15^{\circ} \mathrm{C}$. The optimum foaming water content is indicated in Figure 7 .

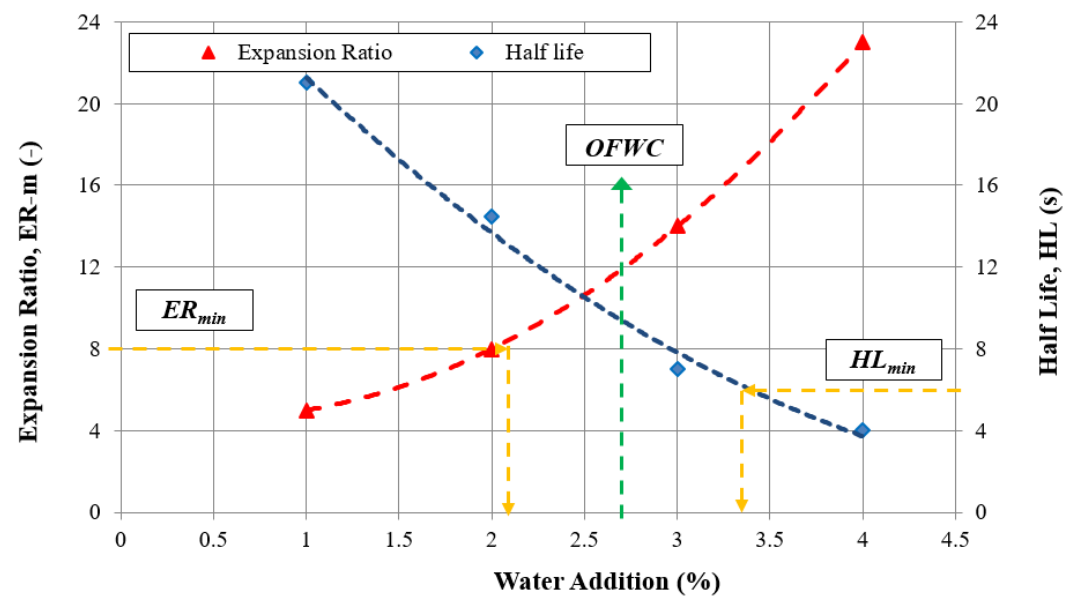

Figure 7. Foaming parameters of paving-grade bitumen 50/70.

The optimum foaming water content (OFWC) for the 50/70 paving-grade bitumen determined in accordance with the data in Figure 7 was $2.7 \%$. As indicated by the authors in [35], measurement 
accuracy is very important for the assessment of OFWC, which is why it is necessary to use state-of-the-art measuring systems [35] or conduct the assessment in such a way as to exclude the effect of external factors.

\subsection{Hydraulic Binder}

The CRM-FB mixture includes Class-I Portland cement with a 42.5 compressive strength and a high early strength (" $\mathrm{R}^{\prime}$ ) conforming to EN 197-1 [36]. The basic properties of CEM I 42,5R Portland cement are compiled in Table 6.

Table 6. Properties of CEM I 42,5R Portland cement.

\begin{tabular}{cccc}
\hline Property & Testing Method & Unit & Result \\
\hline $\begin{array}{c}\text { Beginning of the setting time } \\
\text { Compressive strength }\end{array}$ & EN 196-3 & min & 209 \\
at 2 days & EN 196-1 & MPa & 27.2 \\
at 28 days & MPa & 55.6 \\
Soundness & EN 196-3 & $\mathrm{mm}$ & 0.8 \\
Specific surface area & EN 196-6 & $\mathrm{cm}^{2} / \mathrm{g}$ & 3360 \\
\hline
\end{tabular}

\section{Mixture Design and Sample Preparation}

\subsection{Mixture Design}

For the asphalt mixture, the proportions of the mineral components, $0 / 4 \mathrm{~mm}$ natural dolomite aggregate (VA \# 0/4), 0/31.5 mm natural dolomite aggregate (VA \# 0/31.5) and 0/31.5 mm RAP (RAP \# 0/31.5), were established to ensure conformity with the optimum mixture gradation criterion [33]. In order to achieve the required particle size for the Marshall test [37], the mineral material was passed through a $22.4 \mathrm{~mm}$ sieve. The percentage amount of the mineral components with the optimum gradation is given in Table 7 and shown in Figure 8.

Table 7. Composition of the mineral mixture.

\begin{tabular}{cccc}
\hline Mixture & Aggregate Type & $\mathbf{( \% )}$ & $\begin{array}{c}\text { Particle Density } \\
\boldsymbol{\rho}_{\mathbf{a}}\left(\mathbf{M g} / \mathbf{m}^{\mathbf{3}}\right)\end{array}$ \\
\hline \multirow{3}{*}{ CRM-FB } & RAP \# 0/31.5 & 50.0 & 2.43 \\
& VA \# 0/4 & 25.0 & 2.68 \\
& VA \# 0/31.5 & 25.0 & 2.80 \\
\hline
\end{tabular}

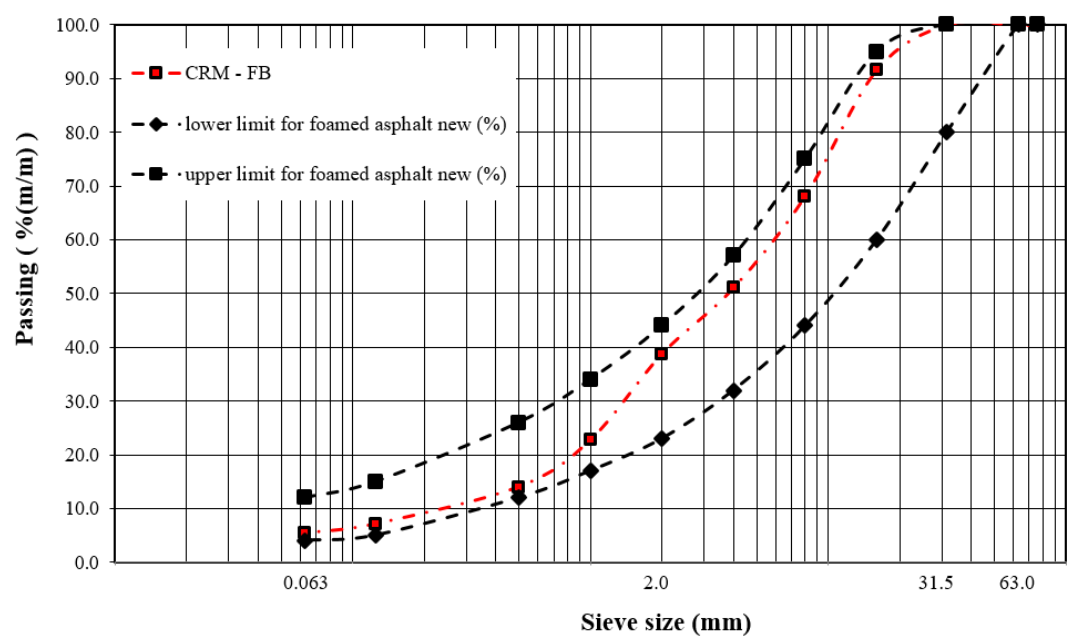

Figure 8. Cold recycled mixture with foamed bitumen (CRM-FB) mixture gradation curve. 
The CRM-FB mixture contained 3.0\% Class-I 42,5R Portland cement, 2.5\% bitumen foam made from 50/70 paving-grade bitumen and 3.0\% redispersible polymer powders dosed by weight. The ultimate composition of the mixture is shown in Table 8.

Table 8. Composition of the cold-recycled mixture with polymers-CRM-FB + P.

\begin{tabular}{cccc}
\hline \multirow{2}{*}{ Component } & \multicolumn{2}{c}{ Percent Content (\%) } \\
\cline { 2 - 4 } & MM & (R) CRM-FB & (P1-4) CRM-FB \\
\hline Reclaimed asphalt pavement (RAP \# 31.5 mm) & 50.0 & 47.3 & 45.8 \\
Dolomite aggregate (VA \# 31.5 mm) & 25.0 & 23.6 & 22.9 \\
Dolomite aggregate (VA \#0/4 mm) & 25.0 & 23.6 & 22.9 \\
CEM I 42,5R Portland cement & - & 3.0 & 3.0 \\
Redispersible polymer powder (P1-P4) & - & - & 3.0 \\
50/70 foamed bitumen & - & 2.5 & 2.5 \\
\hline
\end{tabular}

As a result, five cold-recycled mixtures with foamed bitumen were produced. Four of these mixtures-(P1-P4) CRM-FB - contained redispersible polymer powders. The fifth mixture was the RPP-free reference mixture (R)CRM-FB. This approach made is possible to compare and determine the impact of the RPPs on the physical and mechanical properties of CRM-FB mixtures.

\subsection{CRM-FB Preparation and Curing}

The test specimens were prepared in a laboratory mixer with a batch size of $30 \mathrm{~kg}$. Bitumen foam was produced in a laboratory foamer. The optimum moisture content (OMC) in the mixture, as assessed in accordance with EN 13286-2 [38] using the Proctor method, was 5.8\%.

Compaction methods varied depending on the test type. For determining the physical and mechanical properties (i.e., bulk density, water absorption, air void content and indirect tensile strength), the impact Marshall compactor [39] was used with 60 blows per minute and 75 blows per side.

For dynamic tests, that is, for complex modulus $E^{*}$ determination [40], in the direct tension-compression test on cylindrical specimens (DTC-CY), a gyratory compactor [41] was used. The settings were chosen according to the literature data [42]. The number of gyrations was established individually for each mixture to obtain the density at which air void content in the CRM-FB mixture was $V_{m}=10.0 \%$. The required CRM-FB mixture air void content for low volume roads should be within the range of $8-18 \%$, and from $8 \%$ to $15 \%$ for moderate volume roads [43].

The specimens prepared as described above, irrespective of the type of test performed, were kept at $+20 \pm 5{ }^{\circ} \mathrm{C}$ in the molds during the first day. On the following day, the samples were removed from the molds and kept at relative humidity ranging from $40 \%$ to $70 \%$ for 14 days until the test.

\section{Experimental Program}

The assessment of the physical and mechanical properties and resistance to weather allowed determining the extent to which redispersible polymer powders affect the properties of the CRM-FB mixture.

\subsection{Physical Properties}

\subsubsection{Water Absorption by Weight $\left(n_{w}\right)$}

Water absorption [33] is the amount of mass and volume of water that can be absorbed by a sample immersed in water for $24 \mathrm{~h}$ at a temperature of $+25 \pm 5^{\circ} \mathrm{C}$ and then dried to a constant mass. The water absorption $\left(n_{w}\right)$ is calculated in $\%(\mathrm{~m} / \mathrm{m})$ with an accuracy of $0.1 \%$ according to the Formula:

$$
n_{w}=\frac{m_{1}-m}{m} \cdot 100
$$


where: $m_{1}=$ mass of water-saturated sample [2] and $m=$ mass of a dry sample (g).

\subsubsection{Bulk Density—Saturated-Surface-Dry (SSD)}

Bulk density-saturated surface dry (SSD) is the mass per unit volume of the sample, including air-filled voids, at a specified test temperature [44]. The bulk density SSD of the sample $\left(\rho_{b s s d}\right)$ must be calculated with an accuracy of $0.001 \mathrm{Mg} / \mathrm{m}^{3}$ using the following Formula (2):

$$
\rho_{b s s d}=\frac{m_{1}}{m_{3}-m_{2}} \times \rho_{w}
$$

where: $\rho_{b s s d}=$ bulk density (SSD), expressed in megagrams per cubic meter $\left(\mathrm{Mg} / \mathrm{m}^{3}\right) ; m_{1}=$ mass of the dry specimen, expressed in grams $(\mathrm{g}) ; m_{2}=$ mass of the water saturated specimen, expressed in grams $(\mathrm{g}) ; m_{3}=$ mass of the saturated surface dry specimen, expressed in grams $(\mathrm{g})$ and $\rho_{w}=$ density of water at the test temperature, expressed in megagrams per cubic meter $\left(\mathrm{Mg} / \mathrm{m}^{3}\right)$.

\subsubsection{Air Void Content $\left(V_{m}\right)$}

Air void content $V_{m}$ [45] is the volume of air voids in the CRM-FB specimen, expressed as percentage of the overall volume of the specimen, in accordance with Formula (3).

$$
V_{m}=\frac{\rho_{m}-\rho_{b}}{\rho_{m}} \cdot 100 \%
$$

where: $\rho_{m}=$ CRM-FB mixture density $\left(\mathrm{Mg} / \mathrm{m}^{3}\right)$ and $\rho_{\text {bssd }}=$ CRM-FB mixture bulk density $\left(\mathrm{Mg} / \mathrm{m}^{3}\right)$.

\subsection{Mechanical Properties}

\subsubsection{Indirect Tensile Strength $\left(I T S_{D R Y}\right)$}

The indirect tensile strength test $I T S_{D R Y}$ [46] was performed on Marshall specimens with a $101.6 \pm 0.3 \mathrm{~mm}$ diameter and a $62.5 \pm 2.5 \mathrm{~mm}$ height, cured for 28 days at the relative humidity ranging from $40 \%$ to $70 \%$ and a temperature of $+25{ }^{\circ} \mathrm{C}$. The ITS test is performed by placing the specimen between two plates and subjecting it to a constant load at a rate of advance of $50 \pm 2 \mathrm{~mm} / \mathrm{min}$. The $I T S_{D R Y}$ is calculated according to Formula (4).

$$
I T S_{D R Y}=\frac{2 \cdot P}{\pi \cdot h \cdot D}
$$

where: $P=$ maximum force to failure; $h=$ height of the specimen and $D=$ diameter of the specimen.

\subsubsection{Indirect Tensile Strength after Exposure to Water $\left(I T S_{W E T}\right)$}

The indirect tensile strength test $I T S_{D R Y}[46,47]$ was performed on Marshall specimens with a $101.6 \pm 0.3 \mathrm{~mm}$ diameter and a $62.5 \pm 2.5 \mathrm{~mm}$ height, cured for 28 days at the relative humidity ranging from $40 \%$ to $70 \%$ and submerged in water at a temperature of $+25 \pm 5{ }^{\circ} \mathrm{C}$. The test temperature was $+25^{\circ} \mathrm{C}$. The ITS $W E T$ is calculated according to Formula (5).

$$
I T S_{W E T}=\frac{2 \cdot P}{\pi \cdot h \cdot D}
$$

where: $P=$ maximum force to failure; $h=$ height of the specimen and $D=$ diameter of the specimen

\subsubsection{Indirect Tensile Strength after Exposure to Water and Frost $\left(I T S_{W R W+M}\right)$}

The indirect tensile strength test $I T S_{W R W+M}[46,48]$ was performed on Marshall specimens with a $101.6 \pm 0.3 \mathrm{~mm}$ diameter and a $62.5 \pm 2.5 \mathrm{~mm}$ height, cured for 28 days at the relative humidity ranging from $40 \%$ to $70 \%$ and frozen as per the modified AASHTO T283 test procedure [48]. The modification 
involved the use of two freeze/thaw cycles [49]. The test temperature was $+25^{\circ} \mathrm{C}$. The $I T S_{W R W+M}$ is calculated from Formula (6).

$$
I T S_{W R W+M}=\frac{2 \cdot P}{\pi \cdot h \cdot D}
$$

where: $P=$ maximum force to failure; $h=$ height of the specimen and $D=$ diameter of the specimen.

\subsubsection{Dynamic Modulus in the DTC-CY Test $\left(E^{*}\right)$}

In the DTC-CY test $[40,50]$, the specimen is subjected to a cyclic sinusoidal loading that induces low strains from 25 to $50 \mu \varepsilon$. To obtain a correct sine function for the stress-strain relationship in the linear viscoelasticity range, the cylindrical specimen had to be properly prepared. The specimen was glued with epoxy adhesive to steel plates and the sensors were fixed around the specimen with $120^{\circ}$ spacing. The tests were performed at $-15^{\circ} \mathrm{C}$ and $40^{\circ} \mathrm{C}$, and $10 \mathrm{~Hz}$.

\subsection{Assessment of the Resistance to Weather}

\subsubsection{Moisture Resistance, Tensile Strength Ratio (TSR)}

The tensile strength ratio TSR [47] is the ratio of the tensile strength of water-conditioned specimen, (TSR $W E T)$, to the tensile strength of unconditioned specimen $\left(I T S_{D R Y}\right)$. The TSR is calculated according to Formula (7).

$$
T S R=\frac{I T S_{W E T}}{I T S_{D R Y}}
$$

\subsubsection{Water and Frost Resistance (Modified Method - 2 Freeze/Thaw Cycles), $\left(W R_{W+M}\right)$}

The $W R_{W+M}[47,49]$ defines a drop in the indirect tensile strength of specimens subjected to water and frost damage $\left(T S R_{W R W+M}\right)$ relative to unconditioned specimens $\left(I T S_{D R Y}\right)$. The $W R_{W+M}$ is calculated according to Formula (8).

$$
W R_{W+M}=\frac{I T S_{W R W+M}}{I T S_{D R Y}}
$$

\section{Test Results and Analysis}

\subsection{Effect of RPPs on Compactability of CRM-FB Mixtures}

The process of gyratory compaction of RPP-modified CRM-FB specimens was different from that for RPP-free CRM-FB specimens in that less energy was needed to obtain the assumed air void content of $V_{m}=10 \%$. The decrease in air void content as a function of the number of compaction cycles is shown in Figure 9 and Table 9. 


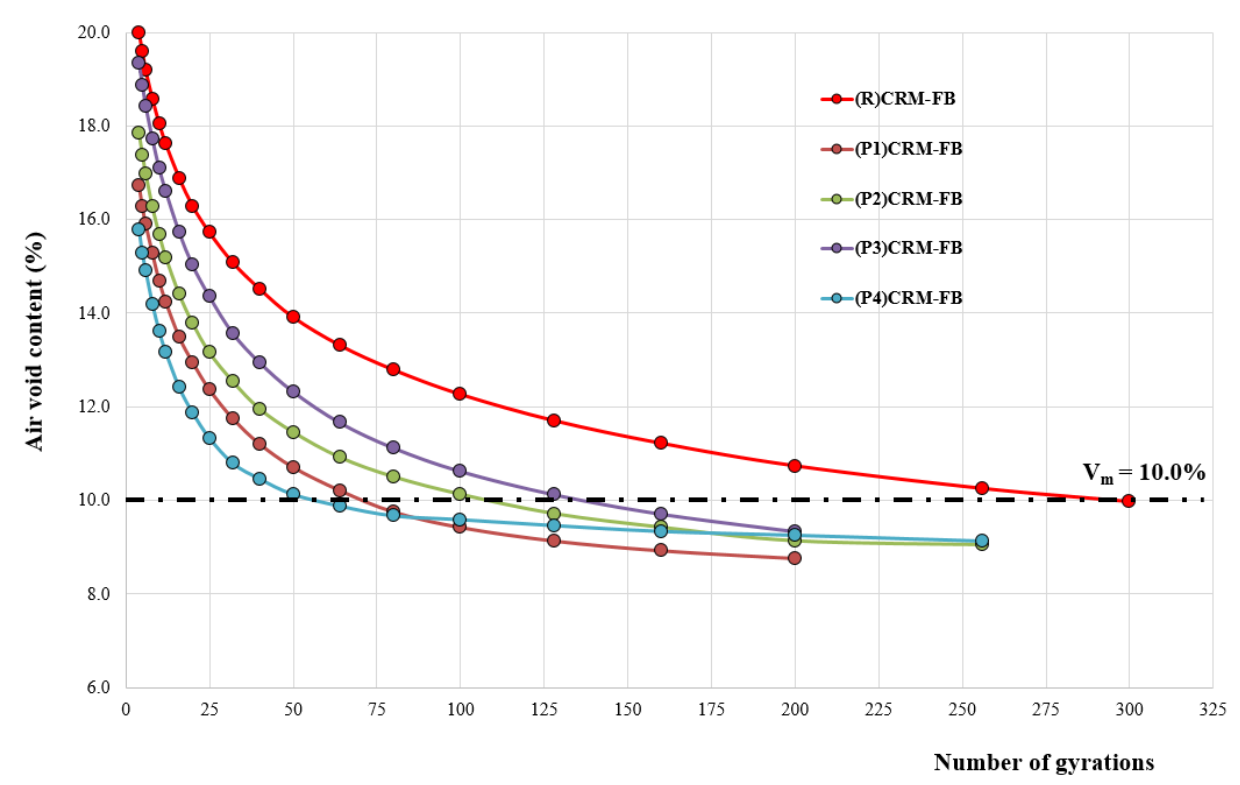

Figure 9. Gyratory compaction of CRM-FB mixture.

Table 9. Number of compaction cycles for $V_{m}=10 \%$.

\begin{tabular}{ccccccc}
\hline & (R)CRM-FB & (P1)CRM-FB & (P2)CRM-FB & (P3)CRM-FB & (P4)CRM-FB \\
\hline Number of compaction cycles & 300 & 64 & 100 & 128 & 58 \\
\hline
\end{tabular}

It is clear (Figure 8) that RPPs have a positive effect on the compaction process. This can be seen in comparison to the reference mixture ((R) CRM-FB) with 3.0\% Portland cement (CEM I 42.5R). Regardless of the type of modifier used, the necessary number of compaction cycles and thus the energy required to achieve the required bulk density $\left(\rho_{\text {bssd }}\right) /$ air void content $\left(V_{m}\right)$ was significantly reduced. With modifiers marked as (P2) and (P3), compared to the number of cycles applied to the reference mixture ((R) CRM-FB), three times fewer cycles were necessary to obtain $V_{m}=10 \%$. For the mixture with modifiers (P1) and (P4), the number of cycles was less than 100. The highest increase in density, and thus a decrease in air void content, was observed in mixtures containing vinyl acetate-vinyl versatate-ethylene-acrylate copolymer (P4). The number of compaction cycles was 58.

In summary, the application of redispersible polymer powders (RPP) was found to have a beneficial effect on the compaction process as it reduced the energy needed to compact the mixture.

\subsection{Results of the Tests of Physical Properties, Mechanical Properties and Resistance to Climate Conditions}

The mean value for each analyzed parameter was determined with a number of replications, ranging from 4 to 6 . The samples of the cold-recycled mixture with foamed bitumen were prepared as described in Section 4.2. The mean values, standard deviation and coefficient of variation for the parameters determined in accordance with the plan of the experiment are given in Tables 10 and 11. 
Table 10. Test results of physical properties and resistance to weather conditions of the CRM-FB mixture.

\begin{tabular}{|c|c|c|c|c|c|c|c|c|c|c|c|c|c|c|c|}
\hline \multirow{2}{*}{$\begin{array}{l}\text { Type of } \\
\text { Mixture }\end{array}$} & \multicolumn{3}{|c|}{$q_{b s s d}\left(\mathrm{Mg} / \mathrm{m}^{3}\right)$} & \multicolumn{3}{|c|}{$n_{w}(\%)$} & \multicolumn{3}{|c|}{$V_{m}(\%)$} & \multicolumn{3}{|c|}{ TSR (\%) } & \multicolumn{3}{|c|}{$W R_{W+M} 2(\%)$} \\
\hline & $x$ & $\mathbf{s}$ & $v(\%)$ & $X$ & s & $v(\%)$ & $X$ & s & $v(\%)$ & $X$ & $\mathbf{s}$ & $v(\%)$ & $x$ & $\mathbf{s}$ & $v(\%)$ \\
\hline (R)CRM-FB & 2.239 & 0.001 & 0.06 & 3.34 & 0.001 & 0.02 & 10.0 & 0.05 & 0.54 & 73 & 6.1 & 8.3 & 70 & 7.7 & 11.1 \\
\hline (P1)CRM-FB & 2.199 & 0.005 & 0.20 & 0.41 & 0.0004 & 0.10 & 8.7 & 0.26 & 2.95 & 59 & 3.0 & 5.1 & 46 & 1.3 & 2.9 \\
\hline (P2)CRM-FB & 2.192 & 0.013 & 0.60 & 1.54 & 0.003 & 0.18 & 9.1 & 0.54 & 6.00 & 61 & 4.7 & 7.7 & 49 & 3.7 & 7.5 \\
\hline (P3)CRM-FB & 2.185 & 0.000 & 0.00 & 2.60 & 0.004 & 0.15 & 9.3 & 0.004 & 0.04 & 41 & 2.0 & 4.8 & 29 & 1.8 & 6.2 \\
\hline (P4)CRM-FB & 2.192 & 0.003 & 0.11 & 0.69 & 0.0005 & 0.07 & 9.0 & 0.10 & 1.15 & 53 & 4.2 & 8.0 & 54 & 3.9 & 7.3 \\
\hline
\end{tabular}

Descriptive statistics: $X$-mean value, $s$-standard deviation of the sample, $v$-coefficient of variation.

Table 11. Results of tests of mechanical properties and resistance to weather conditions of the CRM-FB mixture.

\begin{tabular}{|c|c|c|c|c|c|c|c|c|c|c|c|c|c|c|c|}
\hline \multirow{2}{*}{$\begin{array}{l}\text { Type of } \\
\text { Mixture }\end{array}$} & \multicolumn{3}{|c|}{$I T S_{D R Y}(\mathbf{k P a})$} & \multicolumn{3}{|c|}{$I T S_{W E T}(\mathbf{k P a})$} & \multicolumn{3}{|c|}{$I T S_{W R+W} 2(\mathrm{kPa})$} & \multicolumn{3}{|c|}{$\begin{array}{c}\mathrm{E}^{*}-15^{\circ} \mathrm{C} / 10 \mathrm{~Hz} \\
(\mathrm{MPa})\end{array}$} & \multicolumn{3}{|c|}{$\begin{array}{c}\mathrm{E}^{*}+40^{\circ} \mathrm{C} / 10 \mathrm{~Hz} \\
(\mathrm{MPa})\end{array}$} \\
\hline & $x$ & $\mathbf{s}$ & $v(\%)$ & $x$ & $\mathbf{s}$ & $v(\%)$ & $X$ & $\mathbf{s}$ & $v(\%)$ & $x$ & $\mathbf{s}$ & $v(\%)$ & $X$ & $\mathbf{s}$ & $v(\%)$ \\
\hline (R)CRM-FB & 642 & 46 & 7.10 & 444 & 42 & 9.50 & 389 & 58 & 14.77 & 14774 & 462 & 3.1 & 5116 & 342 & 6.7 \\
\hline (P1)CRM-FB & 892 & 65 & 7.27 & 534 & 11 & 2.14 & 443 & 59 & 13.33 & 13626 & 599 & 4.4 & 2033 & 145 & 7.1 \\
\hline (P2)CRM-FB & 900 & 14 & 1.51 & 548 & 39 & 7.21 & 443 & 27 & 6.04 & 18126 & 994 & 5.5 & 1902 & 154 & 8.1 \\
\hline (P3)CRM-FB & 1046 & 68 & 6.48 & 426 & 8 & 1.93 & 300 & 32 & 10.71 & 16026 & 804 & 5.0 & 2070 & 156 & 7.5 \\
\hline (P4)CRM-FB & 937 & 68 & 7.24 & 495 & 52 & 10.51 & 498 & 47 & 9.40 & 16473 & 934 & 5.7 & 1460 & 115 & 7.9 \\
\hline
\end{tabular}

Descriptive statistics: $X$-mean value, $s$-standard deviation of the sample, $v$-coefficient of variation.

The test results (Tables 10 and 11) show high repeatability in relation to individual results. The coefficient of variation was less than $15 \%$, which was satisfactory for a mixture that contains RAP [51]. The stability of the test results regarding the indirect tensile strength (ITS) may be related to the temperature at which the samples were conditioned before the test, i.e., $+25^{\circ} \mathrm{C}$. A similar correlation was observed by Gandi et al. [52].

The test results indicate that the majority of the CRM-FB properties analyzed were influenced by the addition of RPP. The variability of this influence was analyzed using a multivariate analysis of variance (MANOVA) [53,54] and Tukey's multiple-comparison tests.

\subsection{Multivariate Analysis of Variance and Tukey's Multiple Comparison Test}

For additional evaluation of the effect of modifier type on the physical and mechanical properties and resistance to weather of the CRM-FB mixture, the results were subjected to multivariate analysis of variance (MANOVA) $[53,54]$. The values of intervals of the tested recycled mixtures were normally distributed. The analysis of variance was conducted for all CRM-FB mixtures. The outcome is shown in Table 12.

Table 12. Analysis of variance (MANOVA).

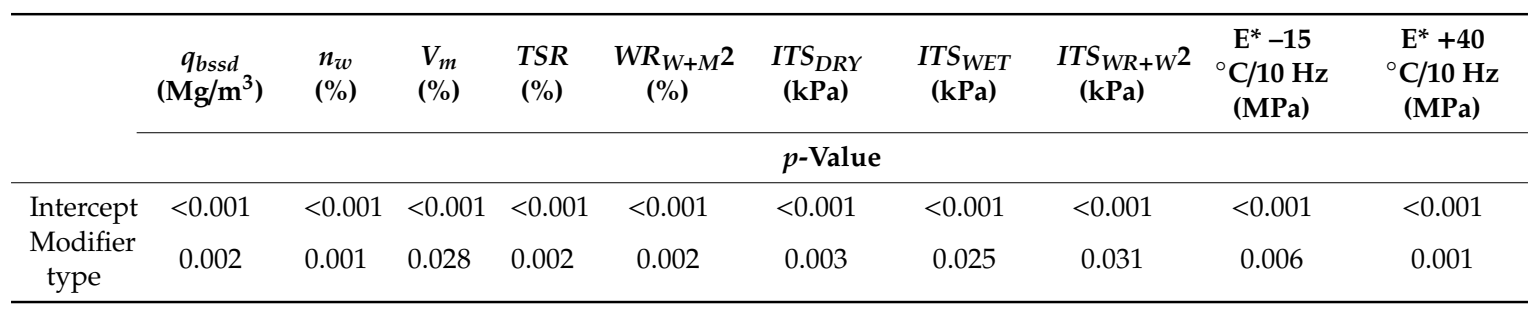

The results of the analysis of variance indicate that all of the considered properties were significantly dependent on the type of CRM-FB mixture (modifier type). The $p$-value was smaller than the assumed significance level $(\alpha=0.05)$, hence with a 5\% error the null hypothesis should be rejected [55]. The obtained values differed from each other, and the properties of the CRM-FB mixture are related to the type of modifier used. 
To verify the data, a multiple comparison test (Tukey's test) of the interdependent groups was performed in terms of the modifier type used in the mixture. Significant differences between mean pairs were based on the characteristics obtained from the analysis of variance. This made it easier to identify the differences between the groups and achieve the same significance level for all measurements. The multiple comparison test was preceded by Bartlett's test for homogeneity of variances in the groups [55].

The results of multiple comparisons at the 0.05 significance level (Tukey's test) are summarized in Tables 13-15 and shown in Figures 10-12.

Results of the bulk density, water absorption and air void content are shown in Table 13 and Figure 9. The "***” sign in Tables 13-15 indicates whether the differences between the means of the parameters determined in the particular group were not significantly different from each other.

Table 13. Multiple comparison test of interactions for bulk density, water absorption and air void content.

\begin{tabular}{|c|c|c|c|c|c|c|c|c|c|}
\hline \multirow{3}{*}{ Subclass Number } & \multicolumn{9}{|c|}{$\begin{array}{l}\text { Tukey's HSD Test } \\
\text { Homogeneous Groups, } \alpha=0.05\end{array}$} \\
\hline & \multirow{2}{*}{ Mixture Type } & \multicolumn{2}{|c|}{$\rho_{\text {MCAS }}\left(\mathrm{Mg} / \mathrm{m}^{3}\right)$} & \multicolumn{4}{|c|}{$n_{w}(\%)$} & \multicolumn{2}{|c|}{$V_{m}(\%)$} \\
\hline & & 1 & 2 & 1 & 2 & 3 & 4 & 1 & 2 \\
\hline 4 & (P3)CRM-FB & $* * *$ & & & & $* * *$ & & $* * *$ & $* * *$ \\
\hline 3 & (P2)CRM-FB & $* * *$ & & & $* * *$ & & & $* * *$ & $* * *$ \\
\hline 5 & (P4)CRM-FB & $* * *$ & & $* * *$ & & & & $* * *$ & $* * *$ \\
\hline 2 & (P1)CRM-FB & $* * *$ & & $* * *$ & & & & $* * *$ & \\
\hline 1 & (R)CRM-FB & & $* * *$ & & & & $* * *$ & & $* * *$ \\
\hline
\end{tabular}

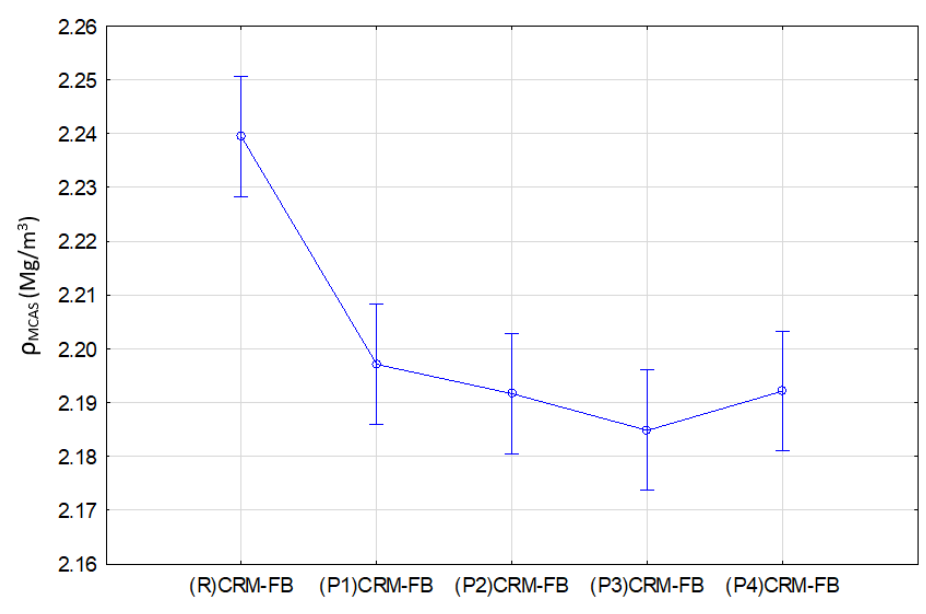

a)

Figure 10. Cont. 


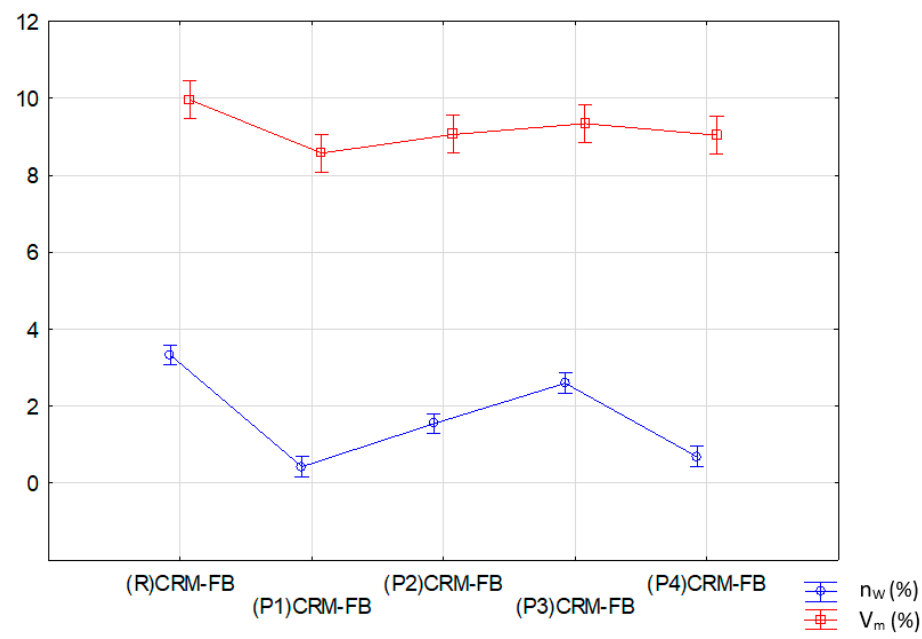

b)

Figure 10. Effect of the modifier type on: (a) bulk density $\left(\rho_{M C A S}\right)$ and (b) water absorption $\left(n_{w}\right)$, and air void content $\left(V_{m}\right)$.

Tukey's test results indicate a significant difference in the effects of the modifier on bulk density $\left(\rho_{M C A S}\right)$, water absorption by weight $\left(n_{w}\right)$ and air void content $\left(V_{m}\right)$. Two similarity groups were identified for the bulk density $\left(\rho_{M C A S}\right)$ and air void content $\left(V_{m}\right)$ characteristics.

The grouping for bulk density $\left(\rho_{M C A S}\right)$ indicates that the type of modifier did not have a statistically significant effect on bulk density. The mixture that differed from the mixtures with the modifier with respect to bulk density was the reference mixture ((R) CRM-FB).

The results of Tukey's test regarding water absorption by weight $\left(n_{w}\right)$ indicate that the set of results essentially includes four groups with statistically significant differences. The lowest water absorption demonstrated the CRM-FB mixtures containing the (P1) and (P4) modifiers. As regards the remaining CRM-FB mixtures, the test results suggest that they varied significantly as compared to other mixtures.

Regarding the air void content $\left(V_{m}\right)$, the comparative analyses demonstrated the presence of two groups with statistically significant differences. However, both groups include CRN-FB mixtures with the same modifier type. Mixtures that demonstrate differences but do not belong to the same groups were the ((P1) CRM-FB) mixture with the air void content $\left(V_{m}\right)=8.7 \%$, and the ((R) CRM-FB) mixture with the air void content $\left(V_{m}\right)=10.0 \%$, i.e., the mixtures with the maximum and minimum air void contents.

The results of the analysis for indirect tensile strength (ITS; before and after conditioning) are summarized in Table 14 and illustrated in Figure 11.

Table 14. Multiple comparison test of interactions for indirect tensile strength.

\begin{tabular}{|c|c|c|c|c|c|c|c|}
\hline \multirow{3}{*}{ Subclass Number } & \multicolumn{7}{|c|}{$\begin{array}{c}\text { Tukey's HSD Test } \\
\text { Homogeneous Groups, } \alpha=0.05\end{array}$} \\
\hline & \multirow{2}{*}{ Mixture Type } & \multicolumn{2}{|c|}{$I T S_{D R Y}(\mathrm{kPa})$} & \multicolumn{2}{|c|}{$I T S_{W E T}(\mathbf{k P a})$} & \multicolumn{2}{|c|}{ ITS $_{W R-W-2}(\mathrm{kPa})$} \\
\hline & & 1 & 2 & 1 & 2 & 1 & 2 \\
\hline 4 & (R)CRM-FB & & $* * *$ & $* * *$ & $* * *$ & $* * *$ & $* * *$ \\
\hline 3 & (P1)CRM-FB & $* * *$ & & $* * *$ & $* * *$ & $* * *$ & $* * *$ \\
\hline 5 & (P2)CRM-FB & $* * *$ & & $* * *$ & & $* * *$ & $* * *$ \\
\hline 2 & (P3)CRM-FB & $* * *$ & & & $* * *$ & $* * *$ & \\
\hline 1 & (P4)CRM-FB & $* * *$ & & $* * *$ & & & $* * *$ \\
\hline
\end{tabular}




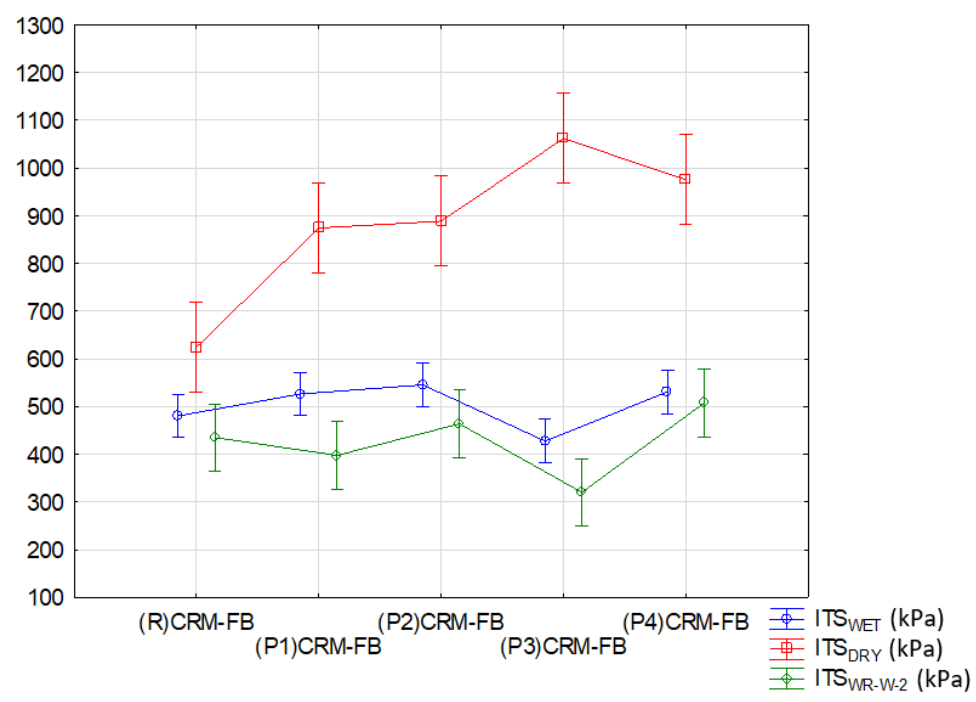

Figure 11. Effect of the modifier type on indirect tensile strength.

Analysis of grouping for indirect tensile strength (ITS) characteristic in terms of conditioning method (Figure 11) indicates that the influence of the modifier was revealed in successive stages of conditioning, that is, exposure to water $\left(I T S_{W E T}\right)$ and to the interaction of water and negative temperatures $\left(I T S_{W R W+M}\right)$.

As regards the indirect tensile strength $\left(I T S_{D R Y}\right)$ of the CRM-FB samples at $+25^{\circ} \mathrm{C}$ without the impact of weather conditions, two statistically significant groups were identified. The first of these includes all mixtures containing the RPP modifier, and the second group is the reference mixture ((R) CRM-FB). This result of the grouping, with only one mixture in a group, indicates that the mixture is completely different from the remaining mixtures. This is due to the fact that the ITS of the RPP-modified CRM-FB was 40-70\% higher (depending on the modifier type) than the ITS for the reference mixture.

The effects of water and the interaction of water and frost resulted in a significant ITS decrease in the CRM-FB specimens, increasing the number of mixtures in the second group. The results of the analysis for $T S R$ and $W R_{W+M 2}$ are summarized in Table 15 and illustrated in Figure 12.

Table 15. Multiple comparison test of interactions for weather conditions (TSR; $\left.W R_{W+M} 2\right)$.

\begin{tabular}{|c|c|c|c|c|c|c|c|}
\hline \multirow{3}{*}{ Subclass Number } & \multicolumn{7}{|c|}{$\begin{array}{c}\text { Tukey's HSD Test } \\
\text { Homogeneous Groups, } \alpha=0.05\end{array}$} \\
\hline & \multirow{2}{*}{ Mixture Type } & \multicolumn{3}{|c|}{ TSR (\%) } & \multicolumn{3}{|c|}{$W R_{W+M} 2(\%)$} \\
\hline & & 1 & 2 & 3 & 1 & 2 & 3 \\
\hline 4 & (R)CRM-FB & & & $* * *$ & & & $* * *$ \\
\hline 3 & (P1)CRM-FB & $* * *$ & & & $* * *$ & $* * *$ & \\
\hline 5 & (P2)CRM-FB & $* * *$ & & & $* * *$ & & \\
\hline 2 & (P3)CRM-FB & & $* * *$ & & & $* * *$ & \\
\hline 1 & (P4)CRM-FB & $* * *$ & $* * *$ & & $* * *$ & & \\
\hline
\end{tabular}




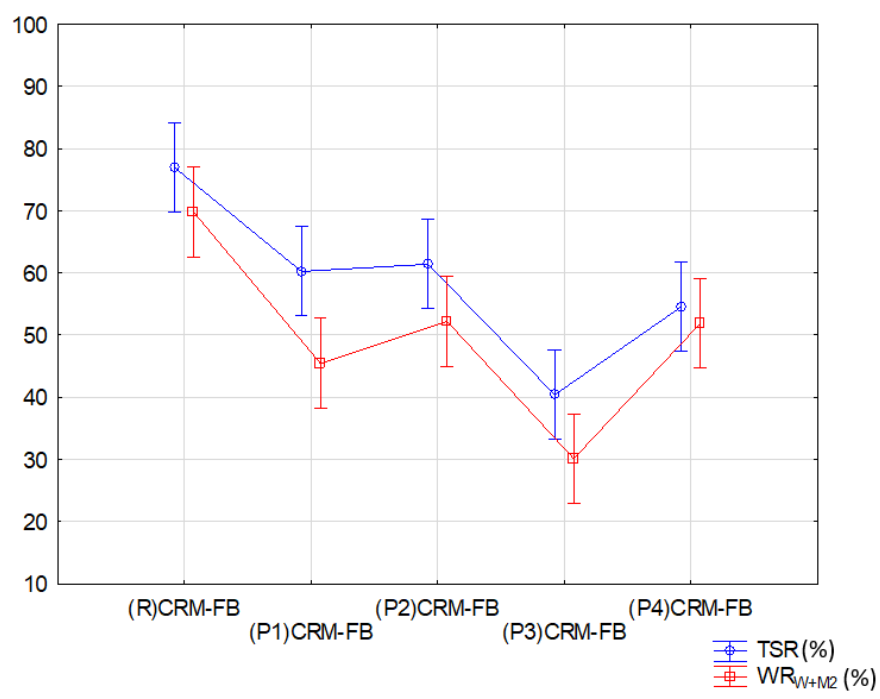

Figure 12. Effect of the modifier type on resistance to weather $\left(T S R ; W R_{W+M} 2\right)$.

The variation results for $(T S R)$ and $\left(W R_{W+M} 2\right)$ were classified in three groups, irrespective of the type of analyzed indicator/factor describing the impact of weather. Identical behavior with respect to the resistance to moisture damage (TSR) and interaction of water and frost $\left(W R_{W+M 2}\right)$ was observed in (P1) CRM-FB, (P2) CRM-FB and (P4) CRM-FB mixtures. The third group, similarly to most of the analyzed parameters, included the (R) CRM-FB reference mixture, which was characterized by the greatest variability in comparison with the mixtures containing the modifier.

The results of the analysis for dynamic modulus $\left(E^{*}\right)$ are summarized in Table 16 and illustrated in Figure 13.

Table 16. Multiple comparison test of interactions for the dynamic modulus.

\begin{tabular}{|c|c|c|c|c|c|c|c|}
\hline \multirow{3}{*}{ Subclass Number } & \multicolumn{7}{|c|}{$\begin{array}{c}\text { Tukey's HSD Test } \\
\text { Homogeneous Groups, } \alpha=0.05\end{array}$} \\
\hline & \multirow{2}{*}{ Mixture Type } & \multicolumn{3}{|c|}{$\mathrm{E}^{*}-15^{\circ} \mathrm{C} / 10 \mathrm{~Hz}(\mathrm{MPa})$} & \multicolumn{3}{|c|}{$\mathrm{E}^{*}+40^{\circ} \mathrm{C} / 10 \mathrm{~Hz}(\mathrm{MPa})$} \\
\hline & & 1 & 2 & 3 & 1 & 2 & 3 \\
\hline 4 & (R)CRM-FB & $* * *$ & $* * *$ & & & & $* * *$ \\
\hline 3 & (P1)CRM-FB & $* * *$ & & & $* * *$ & & \\
\hline 5 & (P2)CRM-FB & & & $* * *$ & $* * *$ & $* * *$ & \\
\hline 2 & (P3)CRM-FB & $* * *$ & $* * *$ & $* * *$ & $* * *$ & & \\
\hline 1 & (P4)CRM-FB & & $* * *$ & $* * *$ & & $* * *$ & \\
\hline
\end{tabular}




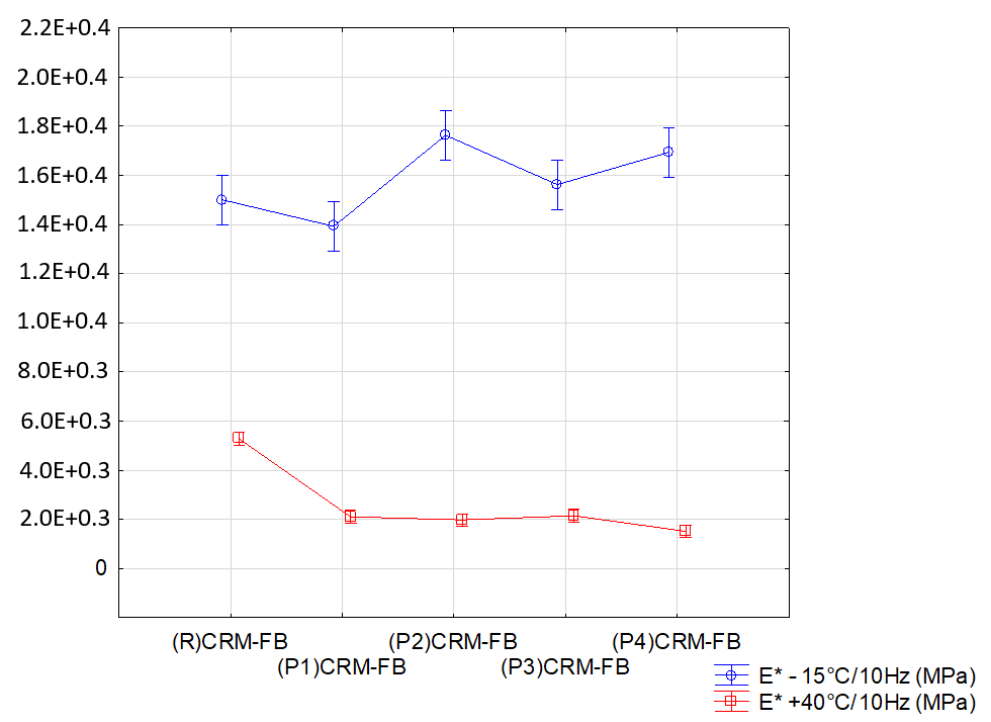

Figure 13. Effect of modifier type on the dynamic modulus.

The grouping obtained in the multiple-comparison tests (Tables 12 and 15) demonstrated that three groups of similarities existed for the complex modulus $\left(\mathrm{E}^{*}\right)$ examined at $-15^{\circ} \mathrm{C}$ and that at +40 ${ }^{\circ} \mathrm{C}$. The groups established for the analyzed properties were not identical, which indicates that the modifiers had different effects on the mixtures at low and high temperatures.

\subsection{Standardization of Test Results}

In order to conclusively determine the impact of the RPPs on the properties of CRM-FB mixtures, the test results were standardized. The results obtained on measurement scales of different properties, e.g., complex modulus $\mathrm{E}^{*}=16026 \mathrm{MPa}$, indirect tensile strength $I T S_{D R Y}=800 \mathrm{kPa}$ and air void content $V_{m}=10 \%$, can be compared if those results are converted into results expressed on a scale with a single, common unit. That is why the test results were standardized. The test results of physical properties, mechanical properties and resistance to weather conditions were converted into a standardized scale using formula (9):

$$
Z=\frac{x-\mu}{\sigma}
$$

where: $x=$ result achieved on the original measurement scale; $\mu=$ mean value of the results for a particular property and $\sigma=$ standard deviation of the results for a particular property.

Standardized values of the results for physical and mechanical properties and resistance to weather are either positive or negative, depending on whether the individual values for the particular mixture deviate up or down from the mean level for ta particular property in the group of mixtures. If the values on the standardized scale are equal to zero $($ " 0 " ), the standardized values are the same as the mean values. Table 17 shows the values after standardization.

Table 17. Standardized test results for the analyzed properties of CRM-FB mixtures.

\begin{tabular}{|c|c|c|c|c|c|c|c|c|c|c|}
\hline \multirow[b]{2}{*}{ Type of Mixture } & \multicolumn{10}{|c|}{$Z$} \\
\hline & $\begin{array}{c}q_{b s s d} \\
\left(\mathrm{Mg} / \mathrm{m}^{3}\right)\end{array}$ & $\begin{array}{l}n_{w} \\
(\%)\end{array}$ & $\begin{array}{c}V_{m} \\
(\%)\end{array}$ & $\begin{array}{l}\text { TSR } \\
(\%)\end{array}$ & $\begin{array}{c}W R_{W+M^{2}} \\
(\%)\end{array}$ & $\begin{array}{c}I T S_{D R Y} \\
(\mathbf{k P a})\end{array}$ & $\begin{array}{c}I T S_{W E T} \\
(\mathbf{k P a})\end{array}$ & $\begin{array}{l}I T S_{W R+W} 2 \\
(\mathbf{k P a})\end{array}$ & $\begin{array}{c}\mathrm{E}^{*}-15 \\
{ }^{\circ} \mathrm{C} / 10 \mathrm{~Hz} \\
(\mathrm{MPa})\end{array}$ & $\begin{array}{c}\mathrm{E}^{*}+40 \\
{ }^{\circ} \mathrm{C} / 10 \mathrm{~Hz} \\
(\mathrm{MPa})\end{array}$ \\
\hline (R)CRM-FB & 1.7 & 1.3 & 1.6 & 1.4 & 1.4 & -1.6 & -0.9 & -0.3 & -0.6 & 1.8 \\
\hline (P1)CRM-FB & -0.1 & -1.0 & -1.1 & 0.1 & -0.2 & 0.1 & 0.8 & 0.4 & -1.3 & -0.3 \\
\hline (P2)CRM-FB & -0.5 & -0.1 & -0.3 & 0.3 & 0.0 & 0.1 & 1.1 & 0.4 & 1.4 & -0.4 \\
\hline (P3)CRM-FB & -0.8 & 0.7 & 0.3 & -1.4 & -1.4 & 1.1 & -1.2 & -1.5 & 0.1 & -0.3 \\
\hline (P4)CRM-FB & -0.4 & -0.8 & -0.4 & -0.4 & 0.3 & 0.4 & 0.1 & 1.1 & 0.4 & -0.7 \\
\hline
\end{tabular}


The effects of the RPPs were evaluated in terms of the physical and mechanical properties of the CRM-FB mixtures. The data obtained (Table 17) were used to present all the standardized results on the radial diagram in Figure 14.

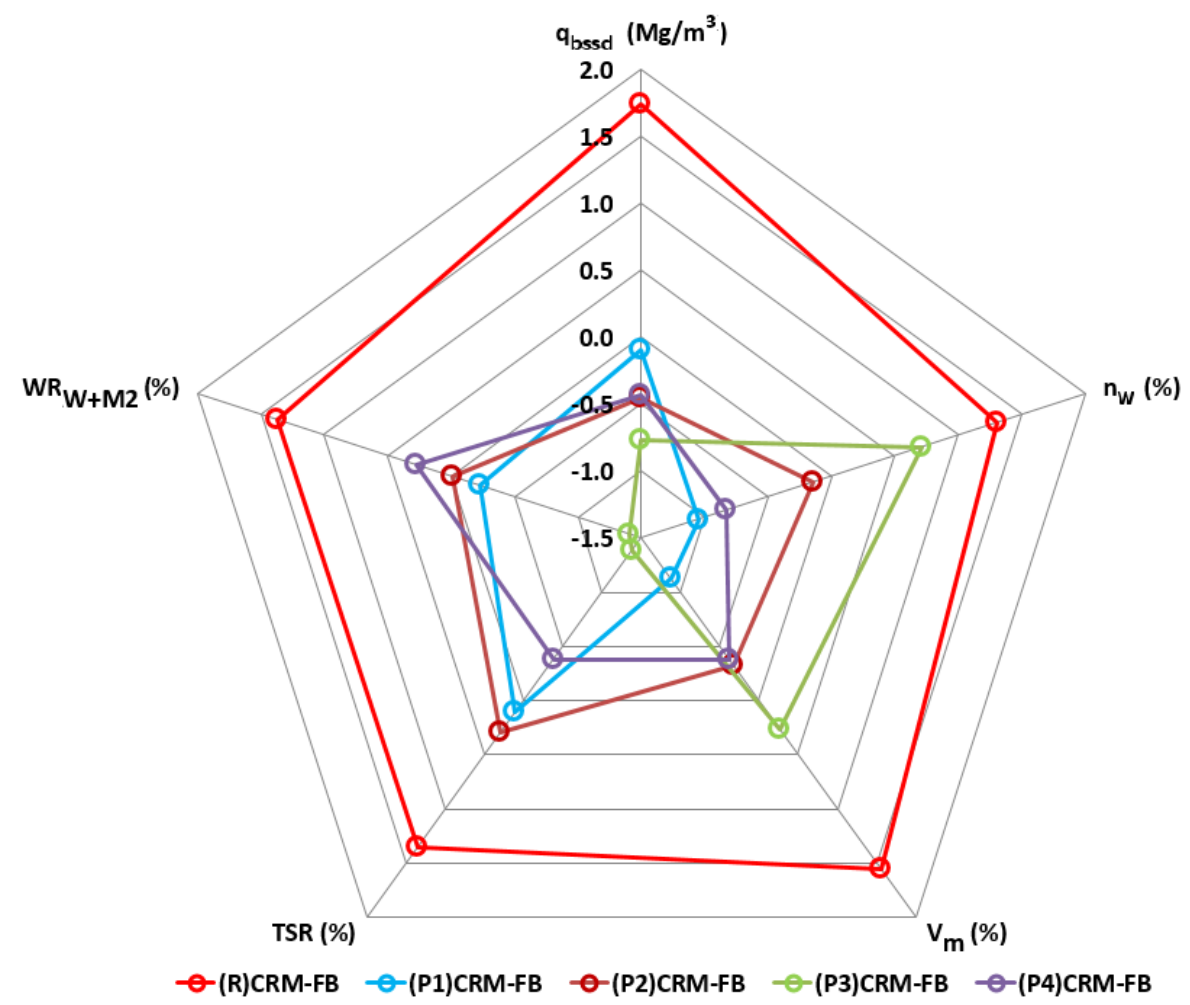

Figure 14. Test results of physical properties and resistance to weather of CRM-FB mixture with RPP (standardized scale).

The red color was used in Figure 14 to mark the values and enveloping lines obtained for the reference mixture ((R) CRM-FB). The test results constitute the reference level for the determination of the change in the properties of the CRM-FB against the type of RPP modifier.

Comparison of the (R) CRM-FB mixture values with those for the RPP-modified mixtures (P1-P4) CRM-FB indicates that the addition of the modifier reduces all of the physical parameters and weather resistance. This relationship was observed irrespective of the modifier type. The addition of the modifier increased the water tightness of the mixture, irrespective of the decrease in bulk density. The highest decrease in water absorption $\left(n_{w}\right)$ and air void content $\left(V_{m}\right)$ was observed in the (P1) RCM-FB mixture, where the polymer powder was based on the vinyl acetate-vinyl versatate copolymer. The lowest water tightness was found in the (P3) CRM-FB mixture with an ethylene-vinyl acetate copolymer (EVA). The reduced air void content and water absorption were positive effects of the polymer modifier on the CRM-FB mixture.

A negative impact of the modifier on the properties of the CRM-FB mixture was observed with respect to moisture sensitivity (TSR) and resistance to water and frost $\left(W R_{W+M} 2\right)$. The modified mixtures showed a greater decrease in indirect tensile strength after conditioning compared with the reference mixture. The (R)CRM-FB mixture showed a 30\% decrease in ITS, and had TSR $=73 \%$ and $W R_{W+M} 2=70 \%$, whereas in the modified mixtures, the ITS decreased by approximately $50 \%$, with TSR $=53 \%$ and $W R_{W+M} 2=44 \%$. The maximum ITS decrease should not exceed $30 \%\left(T S R\right.$ and $W R_{W+M} 2$ ratios should be higher than $70 \%$ ) [43,47]. The higher decrease in the resistance to the effects of water and to the effect of water and frost in the modified mixtures relative to the reference mixture could be related to the RPP production process. The redispersible polymer powders used in the tests contained a water-soluble protective colloid [27] in the form of polyvinyl alcohol (PVA). After conditioning in 
water, the colloid might have been washed out of the mixture samples, which increased the air void content and reduced the indirect tensile strength.

Figure 15 shows the effect of the modifier type on the mechanical properties of the CRM-FB mixture.

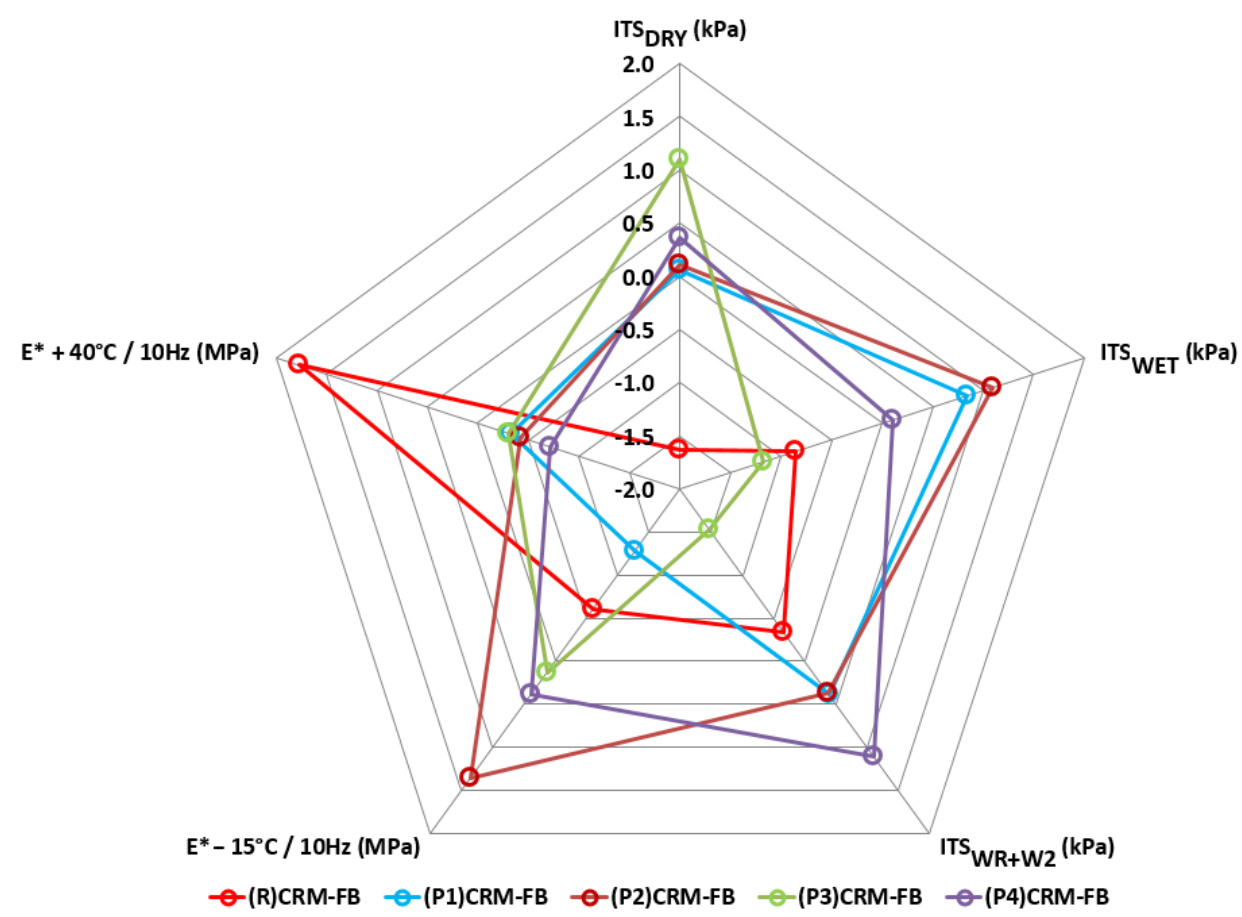

Figure 15. Test results of mechanical properties for the CRM-FB with RPP (standardized scale).

The effect of the modifier on the mechanical properties was different from that observed in physical properties and resistance to weather conditions. The modification of the CRM-FB with RPP increased the values of most parameters. The largest increase after the modification was observed with respect to the ITS of samples conditioned at $+25^{\circ} \mathrm{C}$. The increase in cohesion $\left(I T S_{D R Y}\right)$ relative to the reference mixture was approximately 50\%. Higher ITS of CRM-FB mixtures ensures higher structural reliability. This is due to the distribution of stresses in the structure with a base course made of the CRM-FB mixture [56].

According to the literature data [20], the decrease in complex modulus obtained by the cold-recycled mixture at high temperatures represents a correct relationship. No significant differences in the test results were observed for the complex modulus $\mathrm{E}^{*}$ at $-15^{\circ} \mathrm{C}$, as confirmed by the multiple-comparison analyses (Table 16). At moderate temperatures, complex modulus values decreased [25].

Regarding the unsatisfactory level of resistance to water (TSR) and to the interaction of water and frost $\left(W R_{W+M}\right)$ determined for the modified mixtures, it should be emphasized that the ITS after the conditioning process was much higher than the ITS $S_{W E T}$ obtained for the reference mixture. Similar relationships were found for indirect tensile strength after the samples were conditioned by the exposure to water and frost. To illustrate the effect of the modifier on the ITS change against the reference mixture, the C/ITS change ratio was determined in accordance with Formulas (10) and (11):

$$
C / I T S_{W E T}=\frac{I T S_{W E T-S A M}}{I T S_{W E T-R E F}}
$$

where: $C / I T S_{W E T}=I T S$ change ratio in samples subjected to conditioning through exposure to water; $I T S_{W E T-R E F}=$ indirect tensile strength of samples exposed to water (in accordance with the procedure 
as for the TSR) for the reference mixture and ITS ${ }_{\text {WET-SAM. }}=$ indirect tensile strength of samples exposed to water (in accordance with the procedure as for the TSR) for the RPP-modified mixture;

$$
C / I T S_{W R}=\frac{I T S_{W R-S A M}}{I T S_{W R-R E F}}
$$

where: $C / I T S_{W R}=I T S$ change ratio in samples subjected to conditioning through exposure to water and frost (in accordance with the procedure for $W R_{W+M} 2$ ); ITS $S_{W R-R E F .}=$ indirect tensile strength of samples exposed to water (in accordance with the procedure as for the $W R_{W+M} 2$ ) for the reference mixture and ITS $S_{W R-S A M}=$ indirect tensile strength of samples exposed to water (in accordance with the procedure as for the $W R_{W+M} 2$ ) for the RPP-modified mixture;

The results of the analysis are shown in Figure 16.

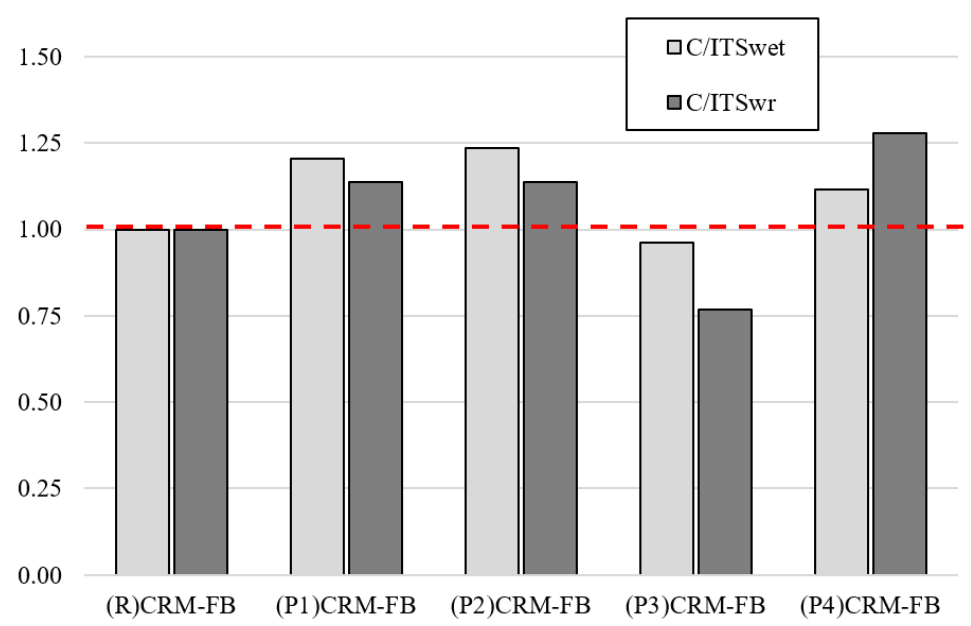

Figure 16. Change ratio of indirect tensile strength after conditioning cycles.

The ITS change ratio after the exposure to water or to the interaction of water and frost (Figure 14) indicates that the RPP modifier increased ITS after conditioning relative to a non-modified mixture. That is why the failure to meet the required TSR and $W R_{W+M} 2$ values was not an objective criterion in this case. For the (P1) modifier, i.e., ethylene-vinyl acetate copolymer (EVA), the ITS was lower than in the reference mixture. In the other cases, ITS was $10-28 \%$ higher.

\section{Conclusions}

The tests for the effect of the type of RPP modifier on the physical and mechanical properties and the resistance to weather conditions supported the following conclusions:

- The use of all analyzed RPPs had a positive effect on the mechanical properties of CRM-FB mixtures. The modification contributed to the increase in cohesion and flexibility with no stiffening of the base layer, i.e., no increase of the modulus of elasticity was observed.

- Maximum cohesion values described by $I T S_{D R Y}$ parameter, more than $1000 \mathrm{kPa}$, were observed when EVA (ethylene-vinyl acetate) was used.

- The addition of redispersible polymer powders (RPP) in the CRM-FB reduced the compaction effort needed to obtain optimum bulk density/air void content. The number of compaction cycles was reduced from 300 to about 100.

- The comparison of the physical and mechanical properties and water and frost sensitivity of the CRM-FB mixtures confirmed that the RPP modifier increased the water tightness of the CRM-FB mixture. 
- The highest impact of the RPP modifier on the CRM-FB mixture was observed with respect to the indirect tensile strength at $+25^{\circ} \mathrm{C}$. The ITS increase ranged from $50 \%$ to $70 \%$ as compared with the RPP-free reference mixture.

- A negative impact of the modifier was observed regarding the water sensitivity (TSR) and the interaction of water and frost $\left(W R_{W+M} 2\right)$. The modified mixtures showed a higher ITS reduction after conditioning in comparison with the reference mixture.

- The indirect tensile strength after conditioning $\left(\left(I T S_{W E T}\right)\right.$ and $\left.\left(I T S_{W R W+M} 2\right)\right)$ was higher than that of the reference mixture. It is thus impractical to assess the water sensitivity and the resistance to water and frost of RPP-modified mixtures through TSR and $W R_{W+M} 2$.

- The addition of any RPP under analysis to the CRM-FB resulted in a significant increase in indirect tensile strength (cohesion $\left(I T S_{D R Y}\right)$ ) accompanied by a simultaneous decrease in complex modulus $\mathrm{E}^{*}$, as compared with the relationships obtained for the reference mixture. This phenomenon is highly desirable in road base courses to provide higher resistance to cracking and mitigate the propagation of existing cracks.

Author Contributions: Conceptualization, P.B.; Methodology, P.B.; Formal Analysis, P.B.; Investigation, P.B.; Resources, P.B. \& M.I.; Writing-Original Draft Preparation, P.B.; Writing-Review \& Editing, P.B. \& M.I.; Visualization, P.B.; Supervision, M.I.; Project Administration, P.B. \& M.I.; Funding Acquisition, M.I.

Funding: This research was funded by financed by the Polish National Science Centre grant number Miniatura 1 No. DEC-2017/01/X/ST8/00831.

Acknowledgments: The study was prepared as part of the project Miniatura 1 No. DEC-2017/01/X/ST8/00831 financed by the Polish National Science Centre.

Conflicts of Interest: The authors declare no conflict of interest.

\section{References}

1. Mazurek, G.; Iwanski, M. Optimisation of the innovative hydraulic binder composition for its versatile use in recycled road base layer. IOP Conf. Ser. Mater. Sci. Eng. 2019, 603, 032044. [CrossRef]

2. Kukiełka, J.; Bańkowski, W. The experimental study of mineral-cement-emulsion mixtures with rubber powder addition. Constr. Build. Mater. 2019, 226, 759-766. [CrossRef]

3. Graziani, A.; Mignini, C.; Bocci, E.; Bocci, M. Complex Modulus Testing and Rheological Modeling of Cold-Recycled Mixs. J. Test. Eval. 2020, 48, 20180905. [CrossRef]

4. Kuchiishi, A.K.; Santos Antão, C.C.D.; Vasconcelos, K.; Bernucci, L.L.B. Influence of viscoelastic properties of cold recycled asphalt mixs on pavement response by means of temperature instrumentation. Road Mater. Pavement Des. 2019, 20, S710-S724. [CrossRef]

5. Chomicz-Kowalska, A.; Gardziejczyk, W.; Iwański, M.M. Moisture resistance and compactability of asphalt concrete produced in half-warm mix asphalt technology with foamed bitumen. Constr. Build. Mater. 2016, 126, 108-118. [CrossRef]

6. Wasilewska, M.; Gardziejczyk, W.; Gierasimiuk, P. Comparison of measurement methods used for evaluation the skid resistance of road pavements in Poland-Case study. Int. J. Pavement Eng. 2018, 1-7. [CrossRef]

7. Bocci, M.; Grilli, A.; Cardone, F.; Graziani, A. A study on the mechanical behaviour of cement-bitumen treated materials. Constr. Build. Mater. 2011, 25, 773-778. [CrossRef]

8. Niazi, Y.; Jalili, M. Effect of Portland cement and lime additives on properties of cold in-place recycled mixs with asphalt emulsion. Constr. Build. Mater. 2009, 23, 1338-1343. [CrossRef]

9. Buczyński, P. The Frost Resistance of Recycled Cold Mixes with Foamed Bitumen and Different Types of Road Binders. Procedia Eng. 2016, 161, 54-59. [CrossRef]

10. Buczyński, P.; Iwański, M. Inactive Mineral Filler as a Stiffness Modulus Regulator in Foamed Bitumen-Modified Recycled Base Layers. IOP Conf. Ser. Mater. Sci. Eng. 2017, 245, 032042. [CrossRef]

11. Ameri, M.; Behnood, A. Laboratory studies to investigate the properties of CIR mixes containing steel slag as a substitute for virgin aggregates. Constr. Build. Mater. 2012, 26, 475-480. [CrossRef]

12. Bańkowski, W. Evaluation of Fatigue Life of Asphalt Concrete Mixtures with Reclaimed Asphalt Pavement. Appl. Sci. 2018, 8, 469. [CrossRef] 
13. Czapik, P.; Zapała-Sławeta, J.; Owsiak, Z.; Stępień, P. Hydration of cement by-pass dust. Constr. Build. Mater. 2020, 231, 117139. [CrossRef]

14. Dołżycki, B.; Jaskuła, P. Review and evaluation of cold recycling with bitumen emulsion and cement for rehabilitation of old pavements. J. Traffic Transp. Eng. 2019, 6, 311-323. [CrossRef]

15. Buczyński, P.; Iwański, M. Fatigue Life Comparison of Recycled Cold Mixes with Foamed Bitumen and with Bitumen Emulsion. Procedia Eng. 2017, 172, 135-142. [CrossRef]

16. Mazurek, G.; Iwański, M. Relaxation Modulus of SMA with Polymer Modified and Highly Polymer Modified Bitumen. Procedia Eng. 2017, 172, 731-738. [CrossRef]

17. Radziszewski, P.; Sarnowski, M.; Pokorski, P.; Kowalski, K.J.; Król, J. High temperature properties of modified bituminous binders produced in Poland. MATEC Web Conf. 2019, 262, 05011. [CrossRef]

18. Zofka, A.; Błażejowski, K. Machine Learning Technique for Interpretation of Infrared Spectra Measured on Polymer Modified Binders. In RILEM 252-CMB Symposium; Poulikakos, L.D., Cannone Falchetto, A., Wistuba, M.P., Hofko, B., Porot, L., Di Benedetto, H., Eds.; Springer International Publishing: Cham, Germanny, 2019; Volume 20, pp. 281-286. ISBN 978-3-030-00475.

19. Shu, B.; Wu, S.; Pang, L.; Javilla, B. The Utilization of Multiple-Walled Carbon Nanotubes in Polymer Modified Bitumen. Materials 2017, 10, 416. [CrossRef]

20. Łukowski, P. Material Modification in Concrete; Ass. of Concrete Producers: Cracow, Poland, 2016; ISBN 978-83-61331-22-3. (In Polish)

21. Kim, H.-J.; Park, J.-Y.; Suh, H.-W.; Cho, B.-Y.; Park, W.-J.; Bae, S.-C. Mechanical Degradation and Thermal Decomposition of Ethylene-Vinyl Acetate (EVA) Polymer-Modified Cement Mortar (PCM) Exposed to High-Temperature. Sustainability 2019, 11, 500. [CrossRef]

22. Gutarowska, B.; Kotynia, R.; Bieliński, D.; Anyszka, R.; Wręczycki, J.; Piotrowska, M.; Koziróg, A.; Berłowska, J.; Dziugan, P. New Sulfur Organic Polymer-Concrete Composites Containing Waste Materials: Mechanical Characteristics and Resistance to Biocorrosion. Materials 2019, 12, 2602. [CrossRef]

23. Shen, Y.; Liu, B.; Lv, J.; Shen, M. Mechanical Properties and Resistance to Acid Corrosion of Polymer Concrete Incorporating Ceramsite, Fly Ash and Glass Fibers. Materials 2019, 12, 2441. [CrossRef] [PubMed]

24. AkzoNobel E ELOTEX Global Product Selection Guide. Available online: http://www.elotex.com/pdf_docs/ ELOTEX\%20Product\%20Selection\%20Guide\%20SA\%202014_en.pdf (accessed on 16 December 2019).

25. Buczynski, P.; Iwanski, M. Rheological properties of mineral-cement mix with foamed bitumen with the addition of redispersible polymer powder. IOP Conf. Ser. Mater. Sci. Eng. 2019, 471, 032013. [CrossRef]

26. Arpagaus, C.; Schafroth, N.; Meur, M. Laboratory scale spray-drying of lactose: A review. Tuberculosis 2010, 3,4 .

27. Ma, H.; Tian, Y.; Li, Z. Interactions between Organic and Inorganic Phases in PA- and PU/PA-Modified-Cement-Based Materials. J. Mater. Civ. Eng. 2011, 23, 1412-1421. [CrossRef]

28. Czarnecki, L. Chemia w Budownictwie; Arkady: Warszawa, Poland, 1995.

29. Chen, X.; Matteucci, M.E.; Lo, C.Y.; Johnston, K.P.; Williams, R.O. Flocculation of Polymer Stabilized Nanocrystal Suspensions to Produce Redispersible Powders. Drug Dev. Ind. Pharm. 2009, 35, 283-296. [CrossRef]

30. Toledo-Madrid, K.; Gallardo-Velázquez, T.; Osorio-Revilla, G. Microencapsulation of Purple Cactus Pear Fruit (Opuntia ficus indica) Extract by the Combined Method W/O/W Double Emulsion-Spray Drying and Conventional Spray Drying: A Comparative Study. Processes 2018, 6, 189. [CrossRef]

31. European Standard: EN 12697-3:2013-10. Bituminous Mixtures-Test Methods for Hot Mix Asphit: Bitumen Recovery: Rotary Evaporator. Available online: https://infostore.saiglobal.com/preview/is/en/2013/i.s. en12697-3-2013.pdf?sku=1636542 (accessed on 16 December 2019).

32. European Standard: EN 12591. Bitumen and Bituminous Binders-Specifications for Paving Grade Bitumens. Available online: https://infostore.saiglobal.com/preview/98698395372.pdf?sku=858114_saig_nsai_nsai_ 2041347 (accessed on 16 December 2019).

33. Wirtgen Cold Recycling Technology. Available online: http://media.wirtgen-group.com/media/02_wirtgen/ infomaterial_1/kaltrecycler/kaltrecycling_technologie/kaltrecycling_handbuch/Cold_recycling_Manual_ EN.pdf (accessed on 16 December 2019).

34. Iwański, M.; Chomicz-Kowalska, A.; Maciejewski, K. Application of synthetic wax for improvement of foamed bitumen parameters. Constr. Build. Mater. 2015, 83, 62-69. [CrossRef] 
35. Iwański, M.; Mazurek, G.; Buczyński, P. Bitumen Foaming Optimisation Process on the Basis of Rheological Properties. Materials 2018, 11, 1854. [CrossRef]

36. European Standard: EN 197-1. Cement: Composition, Specifications and Conformity Criteria for Common Cements. Available online: http://www.rucem.ru/yabbfiles/Attachments/EN-197-1.pdf (accessed on 16 December 2019).

37. Piłat, J.; Radziszewski, P. Nawierzchnie Asfaltowe: Podręcznik Akademicki; Wydawnictwa Komunikacji i Łączności: Warszawa, Poland, 2010; ISBN 978-83-206-1759-7.

38. European Standard: EN 13286-2. Unbound and Hydraulically Bound Mixtures-Test Methods for Laboratory Reference Density and Water Content-Proctor Compaction. Available online: https://www.sis.se/api/ document/preview/75508/ (accessed on 16 December 2019).

39. European Standard: EN 12697-30. Bituminous Mixtures-Test Methods-Specimen Preparation by Impact Compactor. Available online: https://www.sis.se/api/document/preview/80009154/ (accessed on 16 December 2019).

40. European Standard: EN 12697-26. Bituminous Mixtures-Test Methods-Stiffness. Available online: https: //www.sis.se/api/document/preview/80004874/ (accessed on 16 December 2019).

41. European Standard: EN 12697-31. Bituminous Mixtures-Test Methods for Hot Mix Asphalt-Specimen Preparation by Gyratory Compactor. Available online: https:/www.sis.se/api/document/preview/80010373/ (accessed on 16 December 2019).

42. Godenzoni, C.; Graziani, A.; Perraton, D. Complex modulus characterisation of cold-recycled mixtures with foamed bitumen and different contents of reclaimed asphalt. Road Mater. Pavement Des. 2017, 18, 130-150. [CrossRef]

43. Iwański, M.; Chomicz-Kowalska, A.; Buczyński, P.; Mazurek, G.; Cholewińska, M.; Iwański, M.M.; Ramiączek, P.; Maciejewski, K. Procedury Projektowania Oraz Wytyczne Stosowania Materiałów Odpadowych i z Recyklingu do Technologii Wytwarzania Mieszanek Metoda na Zimno z Asfaltem Spienionym (MCAS); Politechnika Świętokrzyska: Kielce, Poland, 2018.

44. European Standard: EN 12697-6. Bituminous Mixtures-Test Methods for Hot Mix Asphalt-Determination of Bulk Density of Bituminous Specimens. Available online: https://www.sis.se/api/document/preview/86181/ (accessed on 16 December 2019).

45. European Standard: EN 12697-8. Bituminous Mixtures-Test Methods-Determination of Void Characteristics of Bituminous Specimens. Available online: https://www. google.com.hk/url?sa=t\&rct=j\&q=\&esrc=s\&source=web\&cd=11\&cad=rja\&uact $=8 \& v e d=$ 2ahUKEwj0wPGa57vmAhUYfnAKHf6yAkY4ChAWMAB6BAgFEAI\&url=https\%3A\%2F\%2Filnas. services-publics.lu\%2Fecnor\%2FdownloadPreview.action\%3FdocumentReference\%3D223450\&usg= AOvVaw2dnfLdfcOHjn7eMkhV_wZm (accessed on 16 December 2019).

46. European Standard: EN 12697-23. Bituminous Mixtures-Test Methods-Determination of the Indirect Tensile Strength of Bituminous Specimens. Available online: https://www.sis.se/api/document/preview/8029788/ (accessed on 16 December 2019).

47. Wirtgen Group Podręcznik Recyklingu na Zimno. Available online: https://www.wirtgen.de (accessed on 16 December 2019).

48. Aashto, T. Standard Method of Test for Resistance of Compacted Asphalt Mixtures to Moisture-Induced Damage; AASHTO Provisional Standards: Washington, DC, USA, 2014.

49. Jaskula, P.; Judycki, J. Durability of Asphalt Concrete Subjected to Deteriorating Effects of Water and Frost. J. Perform. Constr. Facil. 2016, 30, C4014004. [CrossRef]

50. Buczyński, P.; Iwański, M. Complex modulus change within the linear viscoelastic region of the mineral-cement mix with foamed bitumen. Constr. Build. Mater. 2018, 172, 52-62. [CrossRef]

51. Iwański, M.; Chomicz-Kowalska, A. Evaluation of the effect of using foamed bitumen and bitumen emulsion in cold recycling technology. In Sustainability, Eco-efficiency, and Conservation in Transportation Infrastructure Asset Management; Losa, M., Papagiannakis, T., Eds.; CRC Press: Boca Raton, FL, USA, 2014; pp. 69-76. ISBN 978-1-138-00147-3.

52. Gandi, A.; Cardenas, A.; Sow, D.; Carter, A.; Perraton, D. Study of the impact of the compaction and curing temperature on the behavior of cold bituminous recycled materials. J. Traffic Transp. Eng. 2019, 6, 349-358. [CrossRef]

53. Grice, J.W.; Iwasaki, M. A Truly Multivariate Approach to Manova. AMR 2009, 12, 199. [CrossRef] 
54. Hair, J.F. (Ed.) Multivariate Data Analysis, 6th ed.; Pearson Prentice Hall: Upper Saddle River, NJ, USA, 2006; ISBN 978-0-13-032929-5.

55. Montgomery, D.C. Design and Analysis of Experiments, 8th ed.; John Wiley \& Sons, Inc.: Hoboken, NJ, USA, 2013; ISBN 978-1-118-14692-7.

56. Buczyński, P. Rehabilitation reliability of the road pavement structure with recycled base course with foamed bitumen. IOP Conf. Ser. Mater. Sci. Eng. 2018, 356, 012016. [CrossRef]

(c) (1)

(C) 2019 by the authors. Licensee MDPI, Basel, Switzerland. This article is an open access article distributed under the terms and conditions of the Creative Commons Attribution (CC BY) license (http://creativecommons.org/licenses/by/4.0/). 